
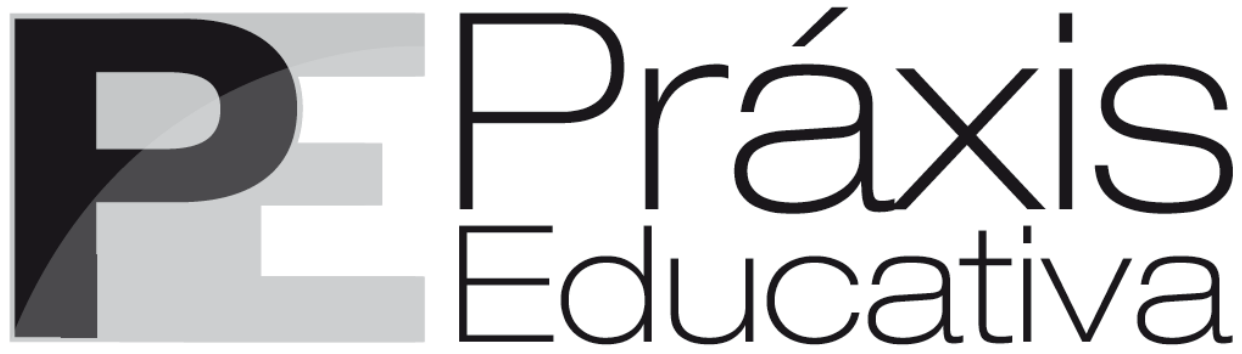

ISSN 1809-4309 (Versão online) DOI: 10.5212/PraxEduc.v.11i2.0006

\title{
Uma "Rocinha" de livros: percursos poéticos dos processos de formação de uma professora alfabetizadora e seus alunos leitores
}

\section{A "Rocinha" of books: poetic paths of the education processes of a literacy teacher and her reader students}

\section{Una "Rocinha" de libros: caminos poéticos de los procesos de formación de una maestra de alfabetización y sus alumnos lectores}

\author{
Maria Francisca Mendes* \\ Carmen Lúcia Vidal Pérez ${ }^{* *}$
}

\begin{abstract}
Resumo: Este artigo busca refletir sobre os processos formativos e a aprendizagem da leitura e da escrita engendrados no cotidiano de uma sala de aula de uma turma de crianças repetentes, a partir das experiências partilhadas entre a professora e seu grupo de alunos. Trata-se de uma investigaçãoformação metodologicamente inspirada na pesquisa narrativa, que tem como fundamentação as formulações benjaminianas sobre experiência e narração e a teoria enunciativa de Bakhtin. Empiricamente, dialogamos com a formação da professora alfabetizadora e com a alfabetização das crianças do primeiro segmento do Ensino Fundamental, a partir de uma ação que tem como aporte a leitura como prática social, desenvolvida junto à comunidade do Laboriaux, Rocinha-RJ.

Palavras-chave: Leitura e escrita. Formação da professora alfabetizadora. Experiência e narrativa na alfabetização.
\end{abstract}

Abstract: This paper reflects upon the training processes and the learning of reading and writing taking place in the daily life of a classroom of backclassed students, from the experiences shared between the teacher and her group of students. It is about research training methodologically inspired by the narrative research, which has its foundation in the benjaminian formulations about experience and narration from Bakhtin's theory of enunciation. Empirically we dialogue with the literacy teacher of education and the literacy of children of the first grades of elementary school, from an action that has framework reading as a social practice, developed with the community of Laboriaux, Rocinha, Rio de Janeiro, Brazil.

Keywords: Reading and writing. Literacy teacher education. Experience and narrative in literacy instruction.

Resumen: El artículo pretende reflexionar sobre los procesos de formación y aprendizaje de la lectura y la escritura producidos en la vida cotidiana de una clase de niños repetidores y de las experiencias compartidas entre la maestra y su grupo de estudiantes. Es un proceso de investigación formación

\footnotetext{
* Secretaria Municipal de Educação do Rio de Janeiro (SMERJ/RJ). E-mail: <francis.mendes@hotmail.com>.

** Professora da Faculdade de Educação e do Programa de Pós-Graduação em Educação da Universidade Federal Fluminense (UFF). E-mail: <clvperez@gmail.com>.
}

Práxis Educativa, Ponta Grossa, v. 11, n. 2, p. 410-433, maio/ago. 2016 Disponível em: <http://www.revistas2.uepg.br/index.php/praxiseducativa > 
Uma "Rocinha" de livros: percursos poéticos dos processos de formação de uma professora...

metodológicamente inspirado en la investigación narrativa, que tiene como fundamento las formulaciones benjaminianas de la experiencia y la narración y la teoría de la enunciación de Bakhtín. Empíricamente se ha dialogado con la formación de la maestra de las clases de alfabetización y con la instrucción de los niños de la escuela primaria, a partir de una acción que comprende la lectura como una práctica social, desarrollada en la comunidad del Laboriaux, Rocinha, RJ.

Palabras clave: Lectura y escritura. Formación de la maestra de alfabetización. Experiencia y narrativa en la alfabetización.

No Brasil, o curso de pedagogia forma professores da Educação Básica que atuarão primordialmente na Educação Infantil e nos anos iniciais do Ensino Fundamental. A tarefa de formação desdobra-se entre a formação inicial e continuada, ou em serviço, e tem como um dos objetivos contribuir com a melhoria do ensino oferecido nas escolas de Educação Básica.

No presente artigo, dobramo-nos sobre as ações de investigação e formação continuada de professoras alfabetizadoras ${ }^{1}$ que desenvolvemos em uma escola de primeiro segmento do Ensino Fundamental localizada no Laboriaux, comunidade da Rocinha, na periferia da zona sul da cidade do Rio de Janeiro ${ }^{2}$. Buscamos refletir sobre os processos formativos engendrados no cotidiano da sala de aula de uma turma de crianças repetentes a partir das experiências partilhadas entre a professora e seu grupo de alunos.

Enquanto as crianças aprendiam a ler e a escrever, a professora também escrevia para aprender sobre o fazer. A questão da leitura e da escrita mostrava-se desafiadora na medida em que as crianças não estavam alfabetizadas, além de necessitarem de apoderar-se da língua em seu sentido mais amplo. Tínhamos dois grandes objetivos a serem alcançados: a apropriação da leitura e da escrita e mais articulação com a realidade na qual as crianças estavam inseridas. A aproximação com a comunidade representava um outro aspecto importante a ser conquistado para que a aprendizagem pudesse fluir com real significação.

Sacristán (1995, p. 98) aponta que "[...] a seleção do currículo, quando se desliga da cultura extraescolar que rodeia os alunos, coloca-lhes uma distância entre o que a escola transmite e o que vivem fora da escola". Acreditamos ser difícil pensar um aprender sem que se efetive uma relação mais próxima com a realidade das crianças. Assim, torna-se necessário manter um diálogo constante entre criação e experiência cotidiana: a leitura e a escrita, impregnadas pela diversidade de experiências sociais e culturais, revelam sujeitos autores e produtores de uma aprendizagem contextualizada e repleta de significados.

\section{A experiência como política de formação de professoras alfabetizadoras}

A realidade expressa em relatórios, avaliações e balanços demonstra que, apesar de tantos esforços, a escola vai mal e a distância entre universidade e Escola Básica é, ainda, um desafio. Observamos que o problema se localiza, principalmente, nos anos iniciais da escolarização, quando as crianças constroem os alicerces cognitivos, sociais, afetivos de suas formas de pensar e conhecer o mundo. Entretanto, no que se refere às crianças das classes populares, a escola ainda fracassa, pois uma grande maioria nela permanece por anos a fio e não aprende a ler e a escrever.

\footnotetext{
${ }^{1}$ A pesquisa insere-se no âmbito do Programa de Apoio a Melhoria da Escola Pública da Fundação de Amparo à Pesquisa do Estado do Rio de Janeiro - FAPERJ.

2 Omitimos o nome da escola por uma questão ética.
}

Práxis Educativa, Ponta Grossa, v. 11, n. 2, p. 410-433, maio/ago. 2016 Disponível em: <http://www.revistas2.uepg.br/index.php/praxiseducativa $>$ 
Acreditamos que o modelo epistemológico de formação de professores, em geral, e de professoras alfabetizadoras, em particular, fundado na dissociação da relação teoria/prática é uma escolha insuficiente e pouco eficaz que fragiliza a formação da alfabetizadora e tem como consequência o insucesso da escola. Tal matriz orienta as políticas e as ações de formação que, de modo geral, se pautam em modelos a serem obedecidos e executados como receituários pelas professoras.

Pensar a formação de professoras alfabetizadoras implica uma reflexão sobre a própria formação acadêmica e pedagógica. O desafio que se coloca é o de considerar como centro da formação (e da ação pedagógica escolar) o saber da experiência, no sentido benjaminiano do termo. Entendemos que os processos formativos se orientam pela reflexão crítica dos saberes das experiências vividas no contexto de trabalho e tecidas no chão da escola, como nos lembra Freire (1996), elementos que alicerçam tanto a formação da professora alfabetizadora, quanto sua própria prática.

Pensamos a educação a partir da experiência e, como tal, propomos, apoiadas em Bakhtin (2000), uma formação ética e estética com vias à produção de conhecimentos a partir do (re)pensar as próprias práticas, entendendo os percursos formativos da professora para além de uma escolha profissional e pessoal - acima de tudo, como uma opção política. A esse respeito, Nagai (2010) esclarece-nos:

[...] todos os atos responsáveis, ou seja, aqueles que nós praticamos na cotidianeidade e que nos fazem sermos singulares, aqueles atos que nos constituem como centros emotivos-volitivos, se concretizam dentro de um universo estético. Nossos atos responsáveis são atos estéticos, possuem uma certa materialidade formal. Como também, nossos atos são éticos e se inserem num determinado campo ético. Essa ética e essa estética não podem ser vistas como algo estático. Ao contrário, se por um lado a arquitetônica que materializa a ética e a estética é algo dado, é uma força histórica, podemos dizer que ela é também um por vir. (NAGAI, 2010, p. 88).

Nossas ações de formação continuada de professoras alfabetizadoras orientam-se pela perspectiva políticoepistemológica ${ }^{3}$ que entende a produção científica como um instrumento mediador da ação pedagógica. Do nosso ponto de vista, tal perspectiva possibilita à professora apreender a complexidade da prática educativa e sua ação como docente, além de potencializar a produção de novos procedimentos e de novas ações para fazer frente às demandas do cotidiano da sala de aula. Entendemos que é no diálogo com o cotidiano da sala de aula que vai sendo tecida uma competência coletiva indispensável para a formação da professora como pesquisadora de sua própria prática, competência fundamental à construção de seu próprio saberfazere e de sua formação profissional.

Buscamos construir com as professoras alfabetizadoras outras possibilidades teóricas e metodológicas para a apropriação do conhecimento, colocando a aprendizagem (seja da criança, ou a sua própria) no centro do processo formativo, pois insistimos em reconhecê-las como capazes de teorizar sobre sua prática. Tal princípio político-epistemológico orienta nossas ações de investigação e formação por concebermos a escola (e seu cotidiano) como "[...] espaço de teoria em movimento permanente de construção, desconstrução, reconstrução" (GARCIA; ZACCUR, 2008, p. 21). Em nossa concepção, a formação de professoras alfabetizadoras é um processo vivo de construção coletiva de conhecimentos que se efetua a partir do e no diálogo com os saberes acadêmicos, os saberes das diferentes áreas de conhecimento escolar (em especial as

\footnotetext{
3 Articular palavras que em uma episteme clássica nos remetem a uma relação causa e efeito, por exemplo, implica fraturar sentidos e significados fixados inventando um novo termo que inclui movimento e fluxo e nos obriga a pensar outras possibilidades para o concebido/vivido.
}

Práxis Educativa, Ponta Grossa, v. 11, n. 2, p. 410-433, maio/ago. 2016 Disponível em: <http://www.revistas2.uepg.br/index.php/praxiseducativa> 
Uma "Rocinha" de livros: percursos poéticos dos processos de formação de uma professora...

formulações relativas à alfabetização) e os saberes das crianças - suas diferentes lógicas operatórias e estilos cognitivos (PÉREZ; ALVES, 2009, p. 54).

A perspectiva adotada funda-se em uma dimensão de criação que afirma o processo de formação como o encontro produzido na emergência do inesperado e nas singularidades nascidas na experiência. Optamos por apostar na ideia de que os caminhos metodológicos vividos com as crianças e as professoras se ancoram em um exercício constante de aproximação e de tensão, de intensificação e de experimentação do pensamento, do afeto, do conhecimento. Enfim, uma formação feita de provocações e de produção de formas outras de compreensão - exercício que produz reflexões sempre em trânsito ${ }^{4}$.

Nossas ações de formação apostam na conversa como metodologia. As conversas constituem-se em dispositivos de produção de uma cultura escolar que reinventa a sala de aula a partir das redes de conversações tecidas por professoras e crianças que, coletivamente, no exercício do diálogo e na atitude da escuta, engendram movimentos de desconstrução e reconstrução de saberes e práticas e possibilitam a emergência de novas experiências. Tal perspectiva entende a formação docente como um tapete tecido a várias mãos: o compartilhar do cotidiano da escola entrelaça movimentos, surpresas e descobertas - movimento de nos constituirmos pesquisadoras junto às crianças, surpresa de sermos desafiadas pelas lógicas próprias da infância e descobertas de que aprendemos com elas - as crianças e suas lógicas (PÉREZ; ALVES, 2009, p. 78).

Metodologicamente, entendemos a formação continuada das professoras alfabetizadoras como um acontecimento resultante do compartilhar e do movimento coletivo de professoras e de crianças que fazem do cotidiano da sala de aula uma possibilidade de aventuras. Tais formulações conduzem-nos a pensar e a praticar (no cotidiano da escola) uma política de formação de professoras alfabetizadoras que toma a prática como referência e afirmação da autoria. Uma política que tem como centralidade os saberes da experiência feitos, como nos lembra Freire. Não é suficiente, portanto, "dar vOz às professoras", mas é preciso incorporar suas experiências e seus saberes na formulação de projetos de reinvenção das práticas alfabetizadoras, do cotidiano da sala de aula e da escola. Uma política de formação que acolhe a multiplicidade de caminhos que se bifurcam porque se definem em função do outro, dos encontros e das conexões das memórias e das experiências pessoais e coletivas.

Tal perspectiva obriga-nos a pensar no sentido da escola, na busca por apropriação/produção de outras leituras (políticas) dos contextos sociais e da palavra escrita, o que exige que a escola (e a sala de aula) funcione como espaço da pergunta, da curiosidade e da investigação.

Em nossa busca por compreender, juntamente às professoras, como fazemos o que fazemos, tomamos a experiência como ato filosófico - em sua espacialidade e temporalidade. A curiosidade é o fio condutor de nossas ações de investigaçãoformação: perguntar como nos leva a observar os diferentes modos de ver e perceber a(s) experiência(s) das professoras em sua singularidade e refletir, coletivamente, sobre ela(s).

Defendemos que a formação (continuada) da professora alfabetizadora precisa ser (re)inventada em sua base epistemológica e em sua função política, o que exige uma política de formação vinculada às práticas cotidianas das professoras. Nesse sentido, pautamos nossas ações de investigaçãoformação em alguns princípios epistemológicos que nos ajudam a (re)pensar e (re)criar

\footnotetext{
${ }^{4}$ A esse respeito ver PÉREZ, C. L. V.; SILVESTRI, M. L. A criação de uma revista eletrônica na escola: uma experiência coletiva de formação. Comunicação apresentada no $36^{\circ}$ ENDIPE. Fortaleza, 2014, p. 13.
}

Práxis Educativa, Ponta Grossa, v. 11, n. 2, p. 410-433, maio/ago. 2016 Disponível em: <http://www.revistas2.uepg.br/index.php/praxiseducativa $>$ 
no cotidiano da escola uma política de formação continuada das professoras alfabetizadoras articulada à reinvenção da prática, de forma a garantir o direito das crianças das classes populares de aprender a ler e a escrever na escola. Tais princípios fundamentam a agenda de nossas ações de investigaçãoformação, a saber:

(i) A formação de professoras alfabetizadoras como um encontro de palavras - espaço discursivo em que a leitura e a escrita são desenvolvidas em uma postura de deixar-se surpreender, afetar, tocar, sensibilizar; enfim, dar as palavras.

(ii) A formação como um ato responsável - que, como micropolítica no cotidiano da escola, engendra um discurso outro que responde as proposições e/ou controvérsias das políticas públicas de formação de professores em geral e de professoras alfabetizadoras em particular.

(iii) A prática como autoria - que incorpora diferentes vozes, experiências e informações no ato singular e criador de aprenderensinar.

(iv) A pesquisa com crianças como ato político - fundada na interlocução, no diálogo e nas relações de alteridade crianças/professoras/pesquisadoras na produção e na socialização de conhecimentos coletivamente engendrados.

Como uma bússola, a agenda tem nos guiado no percurso da pesquisa embora, contraditoriamente, ela se constitua, ao mesmo tempo, no meio e no fim de nossa ação investigativa e formativa.

Optamos por investigar as práticas das professoras alfabetizadoras e seus desdobramentos para os discursos, concepções ou ideias sobre o sentido da escola e do trabalho docente. Tal opção, do nosso ponto de vista, traduz-se em uma ação alternativa de pensar e de praticar a formação continuada de professoras alfabetizadoras a partir da potencialização/produção de performances insurgentes.

\section{A formação da professora alfabetizadora como um ato responsável}

Apostamos em uma prática de investigaçãoformação que pensa a formação continuada de professoras alfabetizadoras como política de formação, ou melhor, como micropolítica cotidiana que reconhece a professora alfabetizadora como sujeito que possui a capacidade de responder aos desafios cotidianos.

Para Bakthin (apud ALVES, 2011), a comunicação humana é um processo ativo - só os humanos são dotados da capacidade de resposta, de interferir, de refutar, de ressignificar, etc., mas também são responsáveis pelo que oferecem como resposta. Concordando com Bakhtin, entendemos a alfabetização como um ato responsável e perguntamos: como a escola (e as políticas públicas) vem respondendo às dificuldades de um grande número de crianças e jovens em se apropriar da leitura e da escrita? Como a escola (e as políticas públicas) vem respondendo às dificuldades das professoras em alfabetizar as crianças das classes populares?

Como professoras, formadoras de professoras envolvidas com a pesquisa acadêmica, situamos nossas ações a partir das práticas engendradas no cotidiano escolar. O cotidiano da escola é o lócus de nossas ações de formação e de investigações teóricas. É deste lugar que 
Uma "Rocinha" de livros: percursos poéticos dos processos de formação de uma professora...

falamos: pesquisar o cotidiano da sala de aula de uma escola de periferia urbana traduz uma forma de pensar a investigação e a formação da professora alfabetizadora como um ato ético compreensão responsiva do mundo, da vida cotidiana, da escola e da sala de aula.

Fundamentadas em Bakhtin (2000), entendemos as práticas discursivas como construções sociais, ou seja, compreendemos as ações das professoras como práticas responsivas gestadas a partir do lugar que ocupam no mundo e na vida. O que vemos do mundo é decorrente do lugar que ocupamos nele. Portanto, a formação da professora alfabetizadora como micropolítica cotidiana fratura paradigmas que sustentam diferentes políticas de alfabetização. $O$ que se observa no cotidiano da escola é que o mundo da vida está dissociado do processo de apropriação da leitura e da escrita. As políticas de alfabetização, de um modo geral, fundamentam-se no "[...] teoreticismo estéril e repetitivo que não tem levado a práticas proficientes de leitura, escrita e compreensão do funcionamento da linguagem em diferentes esferas, em textos diversos e em múltiplos gêneros discursivos" (ALVES, M. P. C., 2011, p. 273). Como nos lembra Manoel de Barros (2010), o mundo não foi feito em alfabeto.

Pensar (e praticar) uma (micro)política cotidiana de formação de professoras alfabetizadoras que subverta a abordagem binária do processo ensino e aprendizagem, invertendo e aglutinando os termos em um movimento contínuo de aprendizagemensino, exige a ruptura com uma história de negação que marca a trajetória escolar da grande maioria das crianças das classes populares, aquelas que não sabem ler, não sabem escrever, não sabem falar. Exige das professoras uma resposta ética (porque responsável) à questão que se coloca: Qual é o meu papel como educadora?

Nesse sentido, investimos prospectivamente em ações de formação que apostam na produção de respostas responsáveis, singularmente produzidas a partir da reflexão coletiva das condições cotidianas de vida e de trabalho e do enfrentamento de questões relativas à desarticulação teoria e prática, à desvalorização da profissão, ao descompasso entre as macro e micropolíticas de formação, à distância que separa a universidade (lócus inicial de formação) e a Escola Básica, etc.

Linguagem e vida não se separam; pelo contrário, confrontam-se e completam-se: a vida entra na linguagem e a linguagem entra na vida a partir de práticas discursivas concretas, e é no ato singular e em sua realização que o sujeito e a linguagem se constituem, "[...] sempre haverá necessidade de que assumamos o nosso lugar único e singular na vida com responsabilidade, pois não temos álibi para a existência” (ALVES, M. P. C., 2011, p. 273).

Este é o desafio que se coloca ao pensarmos (e praticarmos) a formação da professora alfabetizadora em diálogo com a instituição escolar: engendrar uma micropolítica de formação continuada buscando fazer da apropriação da linguagem (especialmente a linguagem escrita) uma experiência estética fundada em uma outra ética, pois é "[...] justamente na experiência estética que o sujeito singular pode usar sua capacidade de criar" (GIOVANI; GARCIA, 2010, p. 99100).

Investir prospectivamente na formação continuada de professoras alfabetizadoras é apostar na produção de outras imagens no presente que orientem nossas ações futuras, pois como lembra Geraldi (2003) é do futuro que tiramos os valores que qualificamos a ação do presente e respondemos responsavelmente ao passado. É ainda Geraldi (2010) quem nos aponta a necessidade de investir em um processo formativo que, ao transformar o vivido em perguntas, ressignifica o processo de aprendizagemensino e a identidade docente.

Práxis Educativa, Ponta Grossa, v. 11, n. 2, p. 410-433, maio/ago. 2016 Disponível em: <http://www.revistas2.uepg.br/index.php/praxiseducativa > 
[...] a nova identidade a ser construída, não é a do sujeito que tem as respostas que a herança cultural já deu para certos problemas, mas a do sujeito capaz de considerar seu vivido, para transformar o vivido em perguntas. $O$ ensino do futuro não estará lastreado nas respostas, mas nas perguntas. Aprender a formulá-las é essencial. (GERALDI, 2010, p. 95).

Buscar respostas responsáveis aos desafios cotidianos é praticar a pedagogia da pergunta (FREIRE; FAUNDEZ, 1991) na formação da professora alfabetizadora, instaurando a reflexão e o questionamento sobre sua prática cotidiana, sobre suas opções teóricas e metodológicas, sobre seus saberes e fazeres, sobre suas angústias, medos e certezas. A professora é um sujeito singular que habita o mundo ético (da escola) com responsabilidade por suas ações concretas definidas, não a partir do passado, mas a partir do futuro, cujas imagens construídas no presente orientam as direções e os sentidos de suas ações.

\section{Narrativa e experiências na formação de professoras alfabetizadoras: um encontro de palavras}

Fazemos uma travessia na companhia das professoras procurando conhecer as diferentes maneiras de fazere narrar as práticas cotidianas. Por certo, a empreitada exige uma maneira de caminhar. Pegadas deixadas pelo caminho são pistas para que suas palavras sejam encontradas - e lidas; não necessariamente compreendidas. Nessa estrada, nós e as professoras alfabetizadoras (pesquisadoras de sua prática) estamos à caça: caçamos os múltiplos sentidos inscritos nas palavras e nas práticas cotidianas.

Assumir a palavra, como ato, significa responsabilizar-se pelo outro por meio de seu dizer "único, irrepetível e insubstituível" (PONZIO, 2010, p. 32). Trata-se de um encontro concreto, estruturado na relação de não indiferença com o outro real. Uma relação responsável que exige responsividade na interação com a palavra outra procurando ressaltar singularidades.

O que falam e/ou escrevem as professoras é produto da interação com o outro, o texto resultante dessa relação está atravessado de outros textos com os quais dialoga. Nesse sentido, a palavra comporta vozes alheias com as quais dialogam imprimindo acentos, objeções, réplicas. Para além de um mero instrumento de comunicação, a palavra constitui a própria experiência do falante.

Considerando este um espaço discursivo, procuramos refletir sobre a formação continuada de professoras alfabetizadoras. A intenção que move nossas ações de investigaçãoformação é olhar a experiência sem objetivos já dados ou contornos definidos. Leitura e escrita são desenvolvidas dentro de uma postura de deixar-se surpreender, afetar, tocar, sensibilizar; enfim, dar as palavras.

\footnotetext{
A escrita, quando transformada em possibilidade de reflexão sobre sua constituição, pelas crianças, $e$ sobre a prática, pela professora, simbolizon o grande diferencial da minha vida de professora alfabetizadora. Eu e as crianças preferimos a condição de incompletude: é ela que nos leva a ousar querer sempre mais. Interagir com as escritas inquietas e vivas que inundam a vida exigiu a ampliação de referenciais de mundo no repensar de processos educacionais arcaicos e descontextualizados. Trabalhar com diferença e afetividade, com percepções e expressões das múltiplas vozes que marcam enunciados, demandou novas atitudes diante do aprender - um aprender cuja exclusividade é partilhada entre crianças e professora. (Trecho da narrativa da professora Sonia, lida no encontro de formação de $3 / 9 / 2013)^{5}$.
}

\footnotetext{
${ }^{5}$ Omitimos o nome da professora por uma questão ética.
}

Práxis Educativa, Ponta Grossa, v. 11, n. 2, p. 410-433, maio/ago. 2016 Disponível em: < http://www.revistas2.uepg.br/index.php/praxiseducativa> 
Uma "Rocinha" de livros: percursos poéticos dos processos de formação de uma professora...

As experiências das professorasnarradoras dialogam com as nossas próprias experiências e inquietudes. Exercitando um olhar exotópico (BAKHTIN, 2000), tentamos, portanto, compreendê-las - e suas leituras e suas vivências. Nas ciências humanas clássicas, esse é um movimento que necessita do distanciamento. $\mathrm{Na}$ investigação no/dos/com os cotidianos, temos que estar implicadas.

Aparentemente, a família de Lolo Barnabé era feliz... mas nem tanto. Ser professora também traz. muitas alegrias... mas nem tantas. Hoje, em minha escola pública situada no lugar mais elevado da Rocinha, o Laboriaux, exerço a função de professora. Encontro-me diariamente com crianças e livros. Costumo comentar que "colocaram uma raposa para cuidar do galinheiro", tal o meu prazer em interagir com os textos literários e sequestrá-los para partilhar com outras professoras, amigos e, principalmente, meu filho. (Trecho da narrativa da professora Sonia, lida no encontro de formação de 14/5/2013).

A filosofia do ato responsável visa entender o fazer parte de um evento e, ao mesmo tempo, buscar um ponto de vista externo na análise dessa arquitetura. Tal escolha leva-nos a um “[...] encontro de palavras em uma descrição participante, a partir de um ponto de vista não indiferente e segundo uma atitude de compreensão respondente" (PONZIO, 2010, p. 42). Construir uma outra palavra é consequência inevitável do encontro com o outro, do sentido de alteridade presente em uma narrativa implicada.

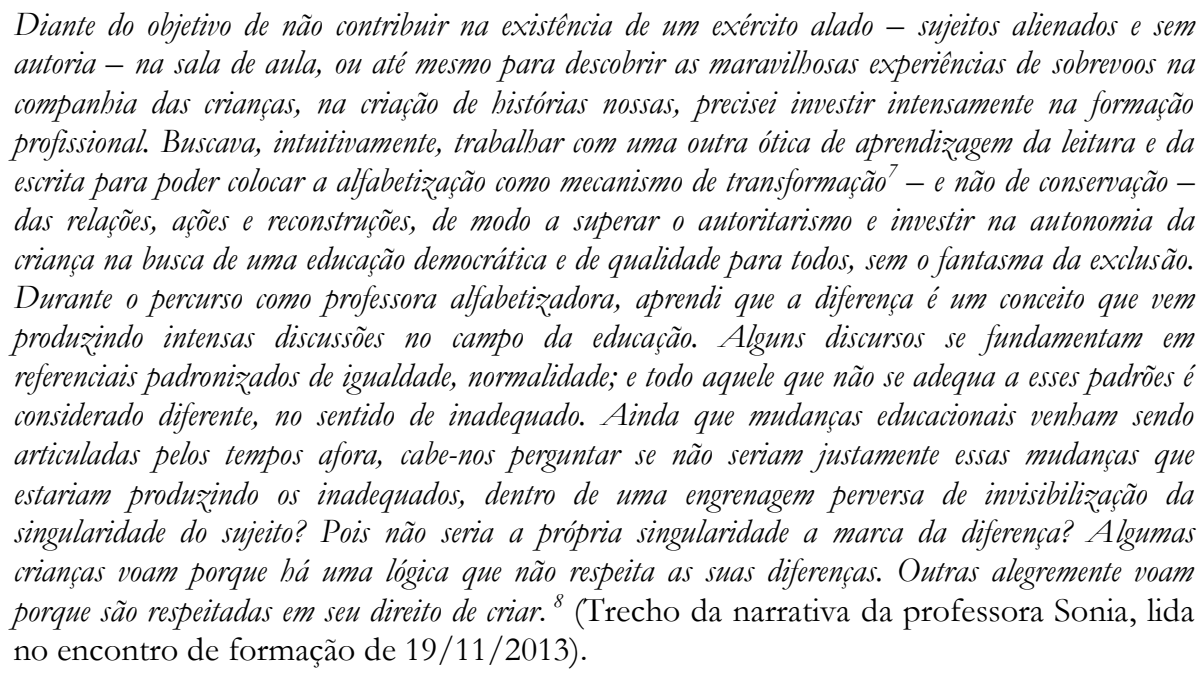

Ver o outro é vê-lo em sua singularidade, considerá-lo como humano, único, sem anular suas diferenças. Ponzio (2010, p. 22) acentua que "[...] não existe armadilha mais mortal que o gênero mais amplo". Corre-se o rico de invisibilizar ainda mais os sujeitos, retirar deles sua capacidade de ser diferente e fazer diferença. Nesse sentido, "[...] cada um é único, com certeza, mas não é único a nível ontológico; é único existindo em relação, na relação com o outro, é único na palavra viva, na outra palavra que se relaciona com uma palavra outra" (PONZIO, 2010, p. 23).

Cada sujeito que compõe um coletivo é único, mas necessita do outro para dizê-lo. Para ouvir a palavra outra é necessário colocar-se em posição de escuta. "[...] dar tempo ao outro, o outro de mim e o outro eu, dar tempo e dar-se tempo" (PONZIO, 2010, p. 25-26). Esse não é

\footnotetext{
${ }^{6}$ FURNARI, E. Lolo Barnabé. São Paulo: Moderna, 2000.

7 Alfabetização como transformação e como invenção, desafio de Luciana Pires Alves. Para saber mais ver ALVES, L. P. Aprender como invenção: outra política cognitiva numa escola (re)inventada. 2013. 324 f. Tese (Doutorado em Educação) - Universidade Federal Fluminense, Niterói, 2013.
}

${ }^{8}$ ROCHA, R. A menina que aprendeu a voar. Rio de Janeiro: Salamandra, 1998.

Práxis Educativa, Ponta Grossa, v. 11, n. 2, p. 410-433, maio/ago. 2016 Disponível em: <http://www.revistas2.uepg.br/index.php/praxiseducativa> 
um tempo determinado; muito menos imposto. É, sim, o tempo necessário - seu e do outro para escutar a razão de cada um como "a única possibilidade de encontro" (PONZIO, 2010, p. 28). Esse é sempre um encontro de palavras.

\title{
Investigação narrativa: um convite à autoria
}

Nos últimos anos, no âmbito da pesquisa acadêmica, tem se destacado o valor formativo de refletir-se sobre a experiência profissional, característica de uma formação em contexto de trabalho. Essa observação, que busca compreender e conceitualizar a realidade, surge na relação entre sujeitos implicados com o saberfazer, resultando na resolução de impasses na sua prática cotidiana. Confere-se, desse modo, um caráter cíclico à aprendizagem na medida em que a observação e a reflexão das experiências vividas levam à busca de respostas para as inquietudes.

Em nossas ações de investigaçãoformação, buscamos (com)partilhar as reflexões suscitadas pelas narrativas escritas das professoras na medida em que compreendemos a produção de narrativas, incorporada ao processo de formação, como um acontecimento estético e assumimos o cotidiano da escola como lócus privilegiado de formação de sujeitos éticos. Nossa concepção de investigaçãoformação leva necessariamente em conta a intencionalidade de problematizar as relações do sujeito (a professora) com sua prática e com outros por meio de um trabalho autoreflexivo das aprendizagens e dos conhecimentos conquistados e de sua participação nesse processo.

\begin{abstract}
Afetar o outro com o mesmo prazer pela leitura e escrita despontou como a intencionalidade maior de meu encontro com as crianças em processo de alfabetização. Inicialmente, entendia ser a alfabetização o dominio de uma técnica. Depois descobri, junto com as crianças, o que mais tarde vim aprender com Geraldi $(2011$, p. 28) que "ao usarmos a lingua falada não estamos preocupados com os sons discretos que a compõem, mas com os sentidos". (Narrativa da professora Sonia, lida no encontro de formação de 20/8/2013).
\end{abstract}

Outro aspecto concernente à investigaçãoformação relaciona-se diretamente ao lugar ocupado pelas integrantes: tanto pesquisadoras quanto professoras são sujeitos participantes na produção coletiva de conhecimentos novos, daí seu caráter abrangente. Distanciadas da concepção de objetos da pesquisa, as professoras em exercício são consideradas autoras no processo de investigação, de problematização e de escritura da prática educativa.

A prática educativa, as relações interpessoais, os dilemas e as contradições subjacentes à ação pedagógica revelam experiências permeadas pela dinâmica relacional coletiva. Identidades e subjetividades encontram-se entrelaçadas afirmando o sujeito como um ser de cultura e de histórias inscrito em suas narrativas: escritas que trazem, entre outros achados, as infâncias da professoracriança na relação com outras crianças - seus alunos.

Finalmente, nas trilhas percorridas entre desconhecidos e conbecidos, nos reconbecemos - eu e as crianças - autoras de palavras significativas porque incorporadas nas experiências individuais e coletivas de todo aquele que vive em permanente processo de aprender. Essas e outras tantas experiências foram tecendo em mim a condição de professorapesquisadora. (Narrativa da professora Sonia, lida no encontro de formação de $27 / 8 / 2013$ ).

Com base nos pressupostos da teoria enunciativa de Bakhtin (2000), destacamos a discursividade na produção de narrativas das práticas, no registro das memórias e nas histórias de vida narradas pelas professoras, na fundamentação teóricoprática e nas reflexões críticas de uma práxis tão produtiva quanto contraditória.

Narrativa e reflexão constituem, assim, os eixos deste estudo, os quais evidenciam o caráter potencializador das histórias que emergem dos sujeitos na busca por produzir novos

Práxis Educativa, Ponta Grossa, v. 11, n. 2, p. 410-433, maio/ago. 2016 Disponível em: <http://www.revistas2.uepg.br/index.php/praxiseducativa $>$ 
Uma "Rocinha" de livros: percursos poéticos dos processos de formação de uma professora...

significados para a docência. Escrever e socializar saberes produzidos na prática cotidiana significa legitimar profissionais e autorias. Essa é uma trajetória em que o comprometimento com a formação intelectual é exigência sem par do processo de pesquisa. As ações de pesquisa que desenvolvemos com as professoras alfabetizadoras acentuam a investigação como projeto de formação, de produção da vida e de elaboração de outros sentidos para a docência.

\begin{abstract}
Atualmente, na rede pública municipal do Rio de Janeiro, livro de literatura e avaliação estão intimamente relacionados. A prova de Produção Textual - proposta de produção de texto para os diversos anos do Ensino Fundamental - vem buscando as obras literárias como referenciais para uma escrita que julgam - os especialistas - ser significativa para quem a escreve justamente por estar pautada na experiência da leitura do texto literário. Diante desse entendimento, crianças e jovens da rede são convidados a escrever frases, ilustrar, escolher personagens e escrever sobre suas características ou ações dentro da história, explicar conflito gerador e suas consequências, escrever resumo observando as etapas de uma narrativa. Ainda que ressalte a função social da leitura, o documento recebido pelas professoras sugere mapear o desempenho da turma a partir das dificuldades apresentadas pelos alunos. Questiono essa estratégia na medida em que "dificilmente poderá ter como consequência o amor pela literatura” (TODOROV, 2010, p. 32). (Narrativa da professora Sonia, lida no encontro de formação de 16/4/2013).
\end{abstract}

Na pesquisa, a polifonia de vozes faz-se sentir na ressonância de nossas palavras (nossas, das professoras e das crianças). Elas passam a dialogar, a buscar caminhos, a aproximar-se da palavra do outro que "[...] não é somente o outro em relação a você, mas é também o outro você, o outro de cada um" (PONZIO, 2010, p. 10). E, como estamos falando de escritas de memórias e narrativas da prática, são múltiplas as razões da escolha do que se contar/narrar. A dinâmica do vivido, expressa nas atitudes e nos sentimentos da professora em cada tempo e lugar, quando registrada, evoca um caráter da permanência.

$\mathrm{Na}$ trajetória das professoras, dois saberes tornam-se presentes: ler e escrever. A leitura e a escrita possibilitam descortinar conhecimentos, promover aprendizagens expressar ideias e sentimentos. Por meio da leitura, deparamo-nos com o universo letrado; enquanto que a escrita nos eleva à condição de autoras. Essa dupla apropriação faz com que nos sintamos pertencentes a um mundo repleto de sentidos, compartilhando experiências que, quando reveladas, deixam de ser individuais para se transformarem em coletivas. Esse é um encontro que se dá conosco e com o outro. Um encontro nem sempre desprovido de riscos.

Penso que o termo literatura baste para nomear a obra literária, sem a necessidade de adjetivações infantil, infanto-juvenil... Um texto literário de qualidade nos captura, se far desejado, se quer partilhado, não exige classificação indicativa. A leitura, como prática social, está estreitamente vinculada à busca pela significação e compreensão do real. Não é possivel gostar de um texto que não nos cativa, envolve ou aprisiona nas tramas tecidas justamente para despertar o prazer das descobertas - nem sempre agradáveis - o penetrar nas fantasias, o desvendar do imaginário. Como professora de alfabetização, por anos lidei com a pedagogização dos textos literários inseridos nos livros didáticos e transformados em literatura escolarizada. Adaptações empobrecidas, perdiam seu referencial convertendo-se em pseudotextos - desconfigurados, fragmentados e sem a criatividade das ilustracõos originais. Ainda que eu me aproprie de fragmentos de textos literários, a intenção é a de contagiar o leitor a ir em busca do original. E apropriar-se também das ilustracōoes consideradas textos estéticos tão belos quanto as histórias narradas. Há pelo menos duas dimensões da prática pedagógica que a interação com a literatura pode produ乏ir: a leitura vista como referencial didático para a aprendizagem da lingua materna ou como representativa para o desenvolvimento da criança a partir de sua inscrição no universo simbólico da cultura. Cada enfoque legitima determinadas práticas de uso do livro. Temos percebido, nos últimos anos, um investimento maciço na literatura dentro da escola pública. Possuímos um acervo literário da maior qualidade. Contudo, não temos conseguido nos desvencilhar de concepções retrógradas que insistem em atrelar litera(lei)tura e avaliação. (Narrativa da professora Sonia, lida no encontro de formação de 30/4/2013).

A partir da escrita de suas narrativas, as professoras alfabetizadoras buscam articular questões pertinentes à prática cotidiana a referenciais teórico-metodológicos presentes em seus

Práxis Educativa, Ponta Grossa, v. 11, n. 2, p. 410-433, maio/ago. 2016 Disponível em: <http://www.revistas2.uepg.br/index.php/praxiseducativa> 
estudos. A produção das narrativas implica um processo reflexivo sobre o saberfazer incorporado ao próprio processo de formação e amplia as possibilidades de entendimento das práticas educativas. Essas vozes, quando socializadas em nossos encontros, ganham mais significações a partir da multiplicidade de interpretações.

Nas dúvidas e nas incertezas que se encontram - ou se confrontam - os sujeitos (as professoras) se veem desafiadas a compreender e a produzir novas formas de serestar em permanente relação com outros sujeitos (as outras professoras, as crianças e suas famílias). Analisar a própria narrativa diante da narrativa do outro promove a descoberta de uma coletividade em sua própria singularidade e redimensiona as reflexões acerca do até então instituído.

Narrar experiências e refletir sobre elas representam possibilidades de socializar saberes e inquietudes e buscar, a partir das trocas com seus pares, ressignificar e superar as próprias indagações. Outras por certo surgirão, pois esse é um percurso que não cessa. Não há uma única forma de expressar-se, assim como são múltiplas as possibilidades de se registrar o vivido. Os registros que se produzem na tessitura das experiências cotidianas contribuem significativamente na formação profissional e nas marcas que revelam o constituir-se humano de um sujeito que é histórico e social. Professoras têm histórias: muitas não as revelam; algumas as reconhecem; outras, além de reconhecê-las, as tornam coletivas pois entendem que é na coletividade que essas histórias são tecidas.

De acordo com Bakhtin (1998), a existência de uma única interpretação acerca de uma enunciação não é possível, principalmente quando se entende a palavra como viva. Longe de situarem-se em um contexto monológico, as enunciações encontram eco em outras enunciações, que passam a interagir entre si em contínuo processo de centralização e descentralização das palavras de uma vivência, de um dia, de um momento.

A palavra de um texto já foi uma palavra falada. Ela surge da memória, do presenciado e do vivido, de outros tempos, lugares, autores. No entanto, essa mesma palavra renova-se por meio de nossa própria $\mathrm{VOz}$, não somente porque o contexto de enunciação é outro, como também novos sentidos a ele são configurados. Palavras estas situadas no interior de uma linguagem que se manifesta sob a perspectiva dialógica e polifônica. Tentamos, portanto, compreendê-las de forma ativa e responsiva cuja "[...] compreensão responsável nada mais é senão a fase inicial e preparatória de uma resposta (seja qual for a forma de sua realização)" (BAKHTIN, 2000, p. 291).

As narrativas das professoras alfabetizadoras carregam enunciados com os quais precisamos interagir concordando ou discordando, completando, ampliando, compreendendo seus discursos, a partir de uma atitude responsiva ativa, na medida em que "[...] toda compreensão é prenhe de resposta e, de uma forma ou de outra, forçosamente a produz: o ouvinte torna-se o locutor" (BAKHTIN, 2000, p. 290).

É no ato de apropriar-se da palavra que se fundam as ações de investigaçãoformação. A intenção é pensar os enunciados à luz dos sujeitos narradores. Sejam palavras interiormente persuasivas, sejam autoritárias (BAKHTIN, 1998) - como identificá-las nessa trama discursiva? escritas ou lidas, faladas ou silenciadas são, todas, palavras. Antes soltas, sem acento, desprovidas de intenção, adquirem forma e passam a povoar histórias e reflexões vivas, dialógicas e autorais.

As experiências inscritas nas narrativas entrecruzam-se, dirigem-se a alguém e recebem deste uma compreensão responsiva ativa, ou seja, são discursos que ocorrem na relação imediata com outros discursos, na corrente de uma comunicação ininterrupta e contextualizada. Bakhtin 
(2000, p. 357, grifos do autor) ressalta que "[...] a palavra quer ser ouvida, compreendida, respondida e quer, por sua vez, responder à resposta, e assim ad infinitum... Ela entra num diálogo em que o sentido não tem fim [...]”.

$\mathrm{Na}$ pesquisa, as palavras das professoras ganham novos horizontes em busca de réplicas e contrapalavras de outras interlocutoras e destinatárias com as quais dividimos um caminhar. $\mathrm{O}$ sentido de nossas ações resume-se a esse encontro. Larrosa aprofunda nosso entendimento:

Para que las palabras duren diciendo cada vez cosas distintas, para que una eternidad sin consuelo abra el intervalo entre cada uno de sus pasos, para que el devenir de lo que es lo mismo sea, en su vuelta a comenzar, de una riqueza infinita, para que el provenir sea leído como lo nunca fue escrito...hay que dar las palabras que hemos recibido. (LARROSA, 2003, p. 117).

O desafio está em efetivar uma prática dialógica na qual a responsabilidade exigida pelas palavras possa conjugar escritas e experiências resultando em um convite à autoria.

\section{Percursos poéticos da investigaçãoformação: uma "Rocinha" de livros}

Conhecida como a maior favela da América Latina, a Rocinha tornou-se bairro em 1993. Localizada na zona sul da cidade do Rio de Janeiro, no morro Dois Irmãos, que separa os bairros de São Conrado e Gávea, a Rocinha é emblemática no que se refere à desigualdade social: a favela-bairro, que abriga mais de 120.000 moradores, que vivem em casas populares, contrasta com as luxuosas residências da classe alta da zona nobre da cidade do Rio de Janeiro.

Figura 1 - Panorâmica da Rocinha - Fotografia de Samara (10 anos)

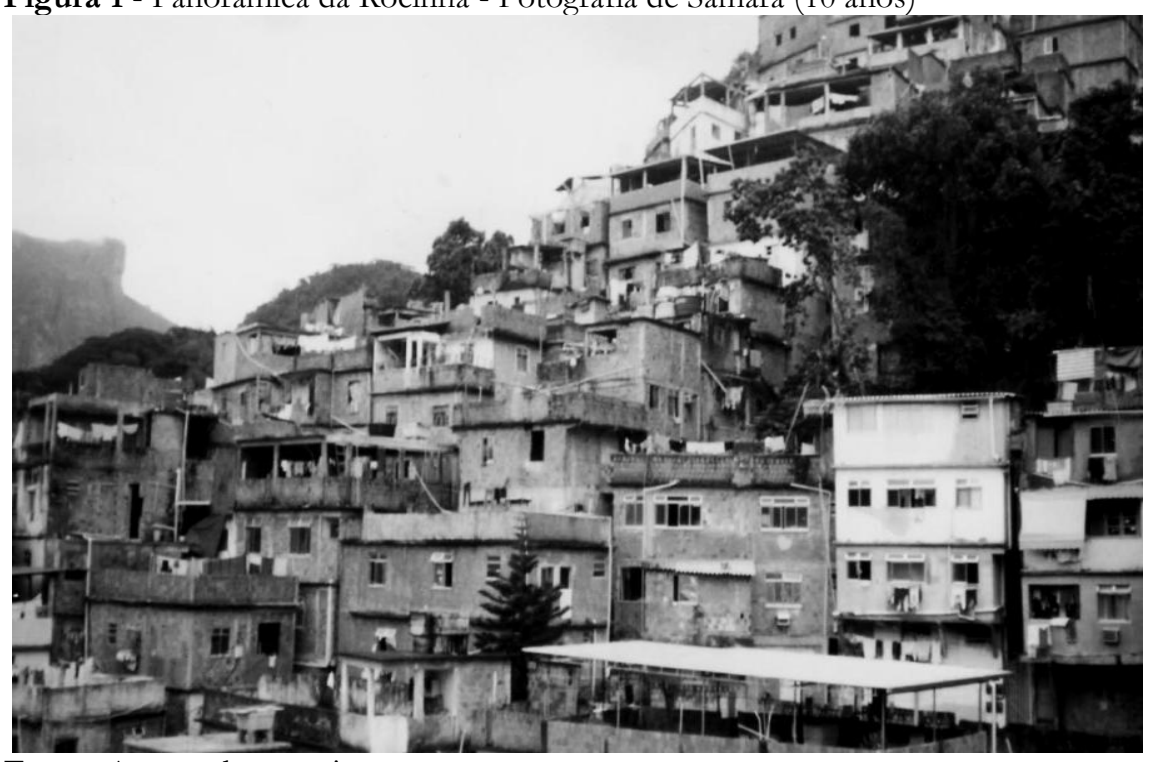

Fonte: Acervo da pesquisa.

A comunidade surgiu na região das chácaras oriundas da Fazenda Quebra Cangalha. A divisão da fazenda em pequenas chácaras, que foram adquiridas por emigrantes portugueses e espanhóis, fornecia as hortaliças que abasteciam as feiras livres da zona sul e eram muito apreciadas por sua origem - a rocinha do alto da Gávea, como eram conhecidas as chácaras, deu origem ao nome da região.

A partir da década de 1940, com o asfaltamento da Estrada da Gávea que corta toda a Rocinha, a ocupação urbana foi acelerada. O fim das chácaras e a vasta extensão de terra "abandonada" atraíram um grande número de migrantes - em sua maioria nordestinos que

Práxis Educativa, Ponta Grossa, v. 11, n. 2, p. 410-433, maio/ago. 2016 Disponível em: <http://www.revistas2.uepg.br/index.php/praxiseducativa > 
fugiam da seca em busca de melhores condições de vida -, que ali se estabeleceram acreditando que aquelas eram terras "sem dono". A abertura dos túneis Rebouças (que liga a zona norte à zona sul) e Dois Irmãos (que liga a zona sul à Barra da Tijuca) ampliou o fluxo de pessoas e a oferta de empregos na região, o que gerou o aumento da população e das áreas ocupadas na Rocinha e deu origem às localidades conhecidas como sub-bairros.

Figura 2 - Panorâmica da Rocinha - Fotografia de Daniel Silva (11 anos)

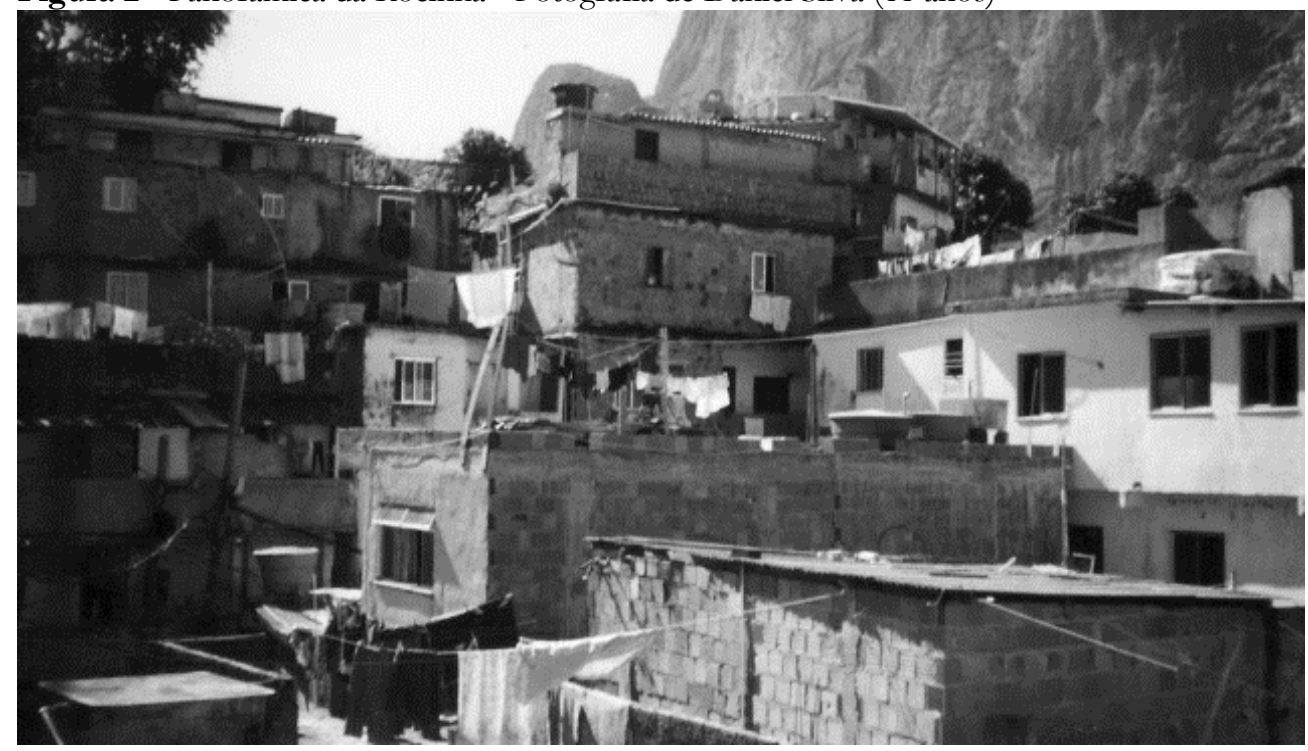

Fonte: Acervo da pesquisa.

Sua geografia é complexa e compreende inúmeras localidades que se dividem em becos, um emaranhado de caminhos que se entrecruzam com a estrada da Gávea e permitem o acesso ao Bairro Barcelos, Largo do Boiadeiro, Vila Verde, Curva do S, Cachopinha, Cachopa, Dionéia, Almir, Vila União, Cidade Nova, Rua Um, Rua Dois, Rua Três, Rua Quatro, Portão Vermelho, Vila Laboriaux, Vila Cruzado, 199, Faz Depressa, Vila Vermelha, Capado, Terreirão, Macega, Roupa Suja e Parque da Cidade.

Figura 3 - Panorâmica da Rocinha - Fotografia de Heitor (11 anos)

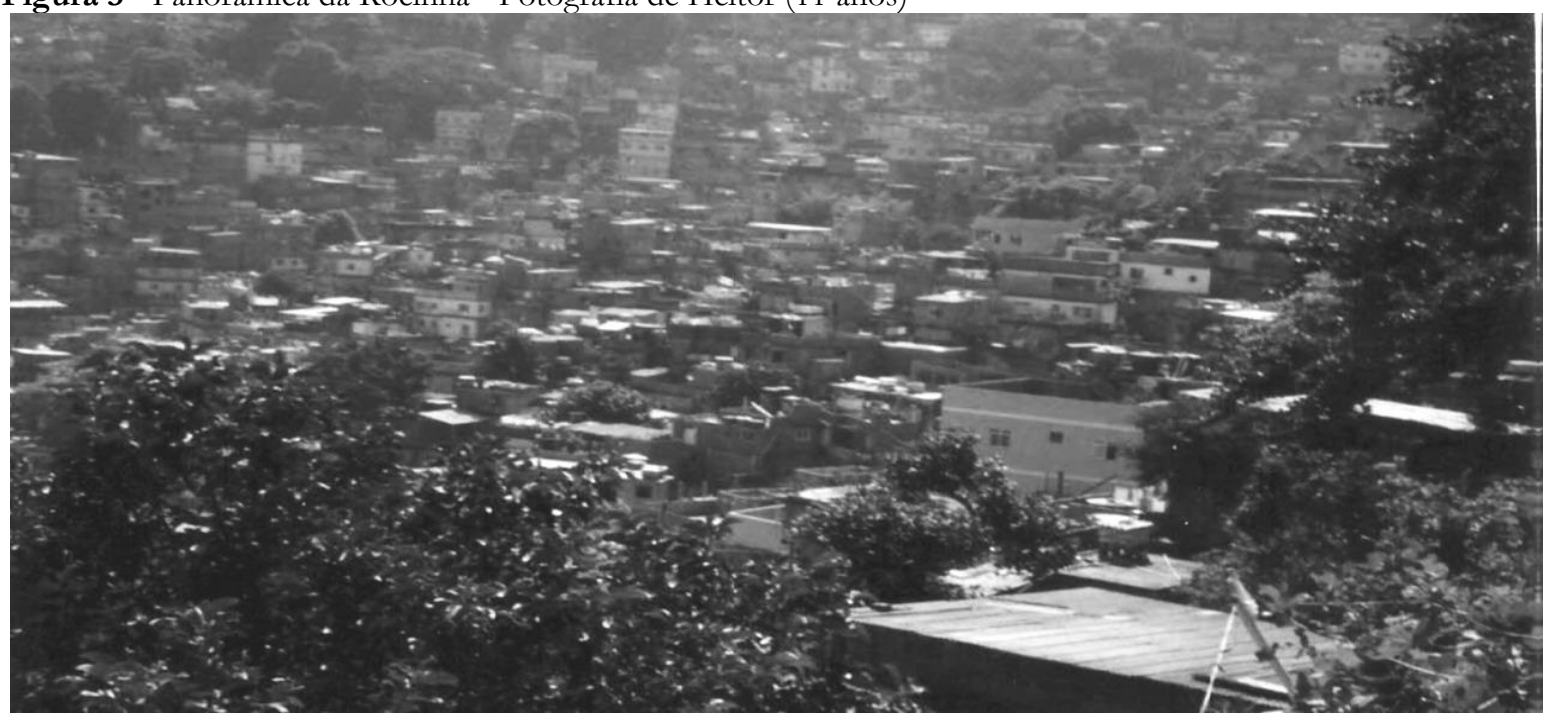

Fonte: Acervo da pesquisa

Quando falamos da Rocinha, é necessário esclarecer de que parte estamos falando, pois é ela composta de múltiplas Rocinhas. No caso deste estudo, estamos falando de um lugar 
Uma "Rocinha" de livros: percursos poéticos dos processos de formação de uma professora...

conhecido como Vila Laboriaux ou, simplesmente, Laboriaux. E, mais especificamente, da experiência de uma professora e seus alunos da escola pública dessa localidade.

Figura 4 - Vista do Alto do Laboriaux - Fotografia de Jéssica (10 anos)

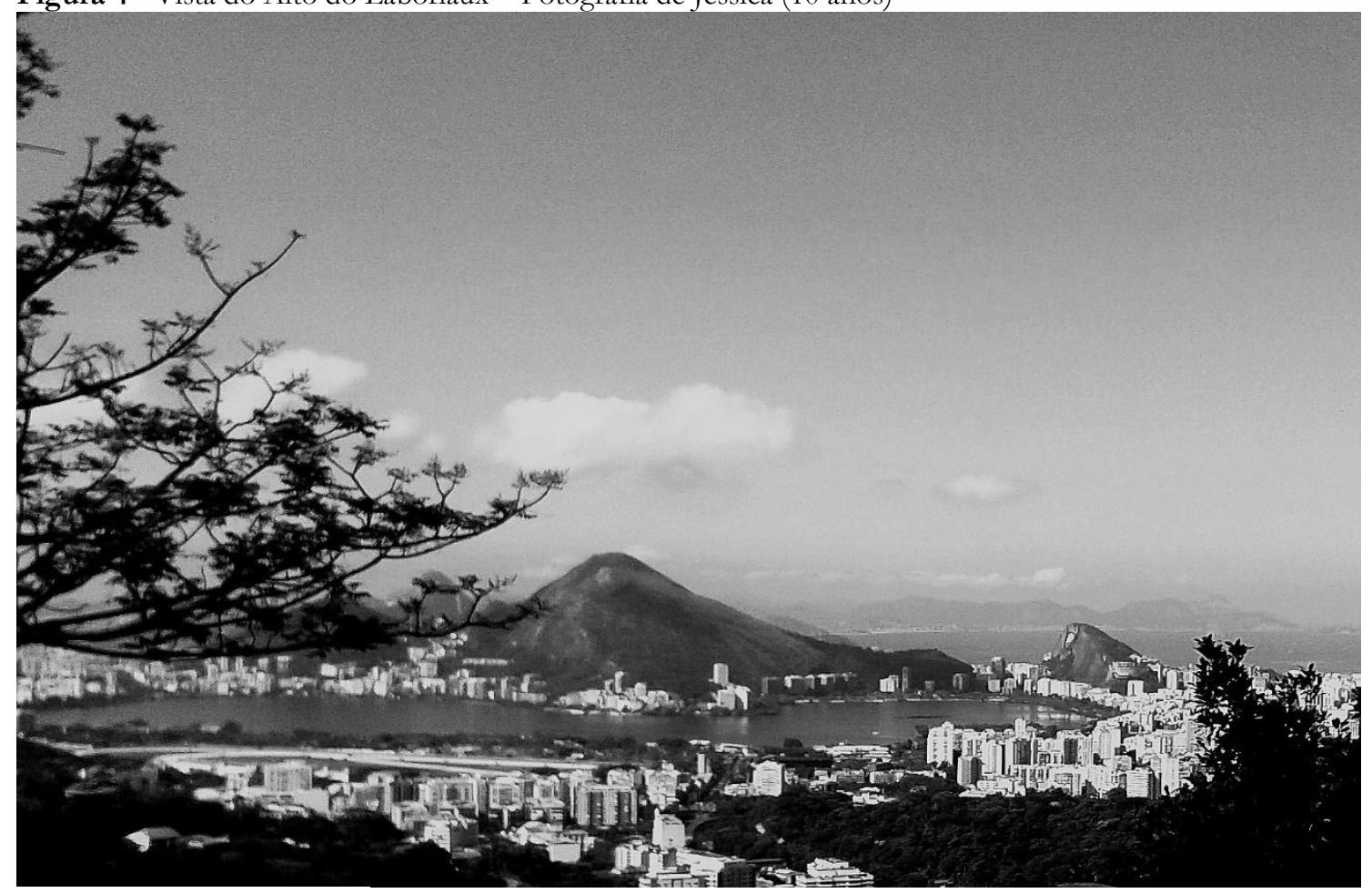

Fonte: Acervo da pesquisa.

Todas as crianças matriculadas na escola pública do Laboriaux são moradoras da Rocinha e oriundas das classes populares de baixa renda. Muitos são filhos de nordestinos que vieram para o Rio de Janeiro em busca de melhores condições de trabalho e de vida. A maioria das mães trabalha como empregadas domésticas e, como todos os moradores da Rocinha, também lutam pela melhoria das condições de vida, pois ainda lhes faltam serviços sociais e programas culturais essenciais para ampliar cada vez mais seus horizontes. Atualmente, a comunidade conta com uma Unidade de Polícia Pacificadora (UPP), o que possibilitou aos moradores vivenciar um pouco mais de segurança e de tranquilidade.

A escola pública do Laboriaux atende a cerca de 270 alunos matriculados em turmas da Educação Infantil ao $5^{\circ}$ ano do Ensino Fundamental. Conta com 6 professoras regentes de turmas (algumas trabalham nos dois turnos) e professoras de sala de leitura, teatro, educação física e inglês. A parte administrativa é composta da diretora e diretora adjunta, secretária e agente educativa. O Laboriaux é um pedaço da Rocinha que abriga mais de 1.000 famílias; e é com essa comunidade que a escola pública desenvolve suas atividades educativas e culturais.

Práxis Educativa, Ponta Grossa, v. 11, n. 2, p. 410-433, maio/ago. 2016 Disponível em: <http://www.revistas2.uepg.br/index.php/praxiseducativa $>$ 
Figura 5 - Laboriaux - Fotografia de Marcela (12 anos)

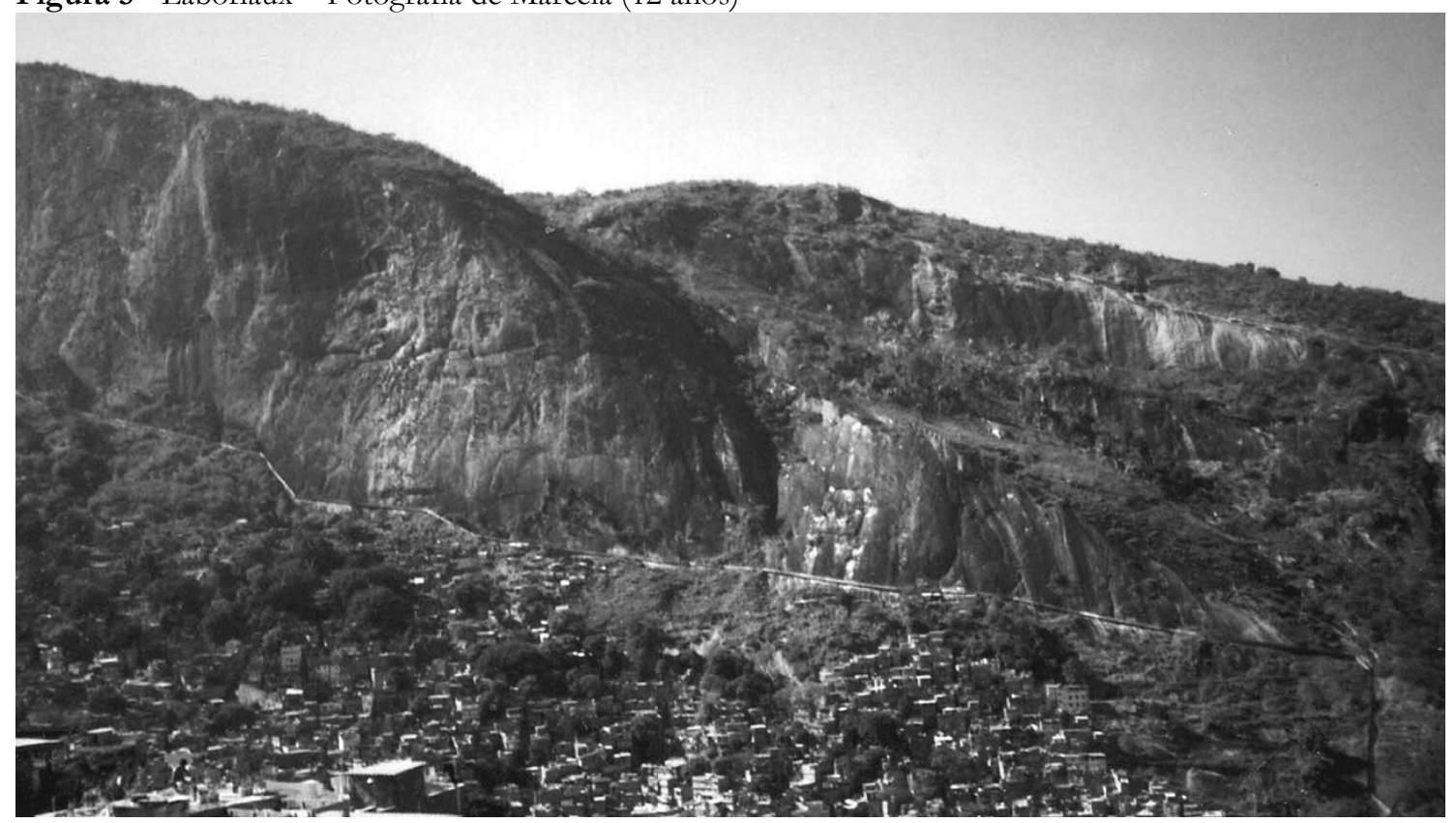

Fonte: Acervo da pesquisa.

\section{Sobre viver e aprender na Rocinha}

Uma professora que gosta de ler e de escrever acaba por estimular nas crianças o mesmo desejo, ainda mais quando a turma - composta de 12 meninos e 12 meninas, com idades entre 9 e 12 anos -, percebia-se diante de tantos obstáculos na relação com a língua materna. Começaram a trilhar juntos um caminhar por inusitadas veredas, nas quais o percurso simbolizava tanto quanto a chegada. Um caminho construído nas pegadas e nos rastros deixados pelas experiências que se materializavam por meio das falas e das escritas de cada um e de todos.

Se a lida é com palavras, faladas ou escritas, o objeto primordial da reflexão deve ser a pessoa que fala e seu discurso. Esse sujeito, para Bakhtin (1998, p. 135), "[...] é um homem essencialmente social, historicamente concreto e definido e seu discurso é uma linguagem social".

Ainda pequena, criada pela avó paterna, descobri o quão triste era não saber ler nem escrever. A tristeza era propriedade minha, não da avó que, feliz, assinava seu nome sem esquecer-se de nenhuma letra. Ela nada lia, mas costurava como ninguém; era a melhor no ofício e a mais respeitada em seu saber; um saber conquistado na lida diária da roça, quando pequena, e que retirou-lhe a oportunidade dos estudos formais. No entanto, sempre valorizou a escola: cedo, aprendi a ler e a escrever e, assim, os segredos escondidos nas palavras e entre elas. No caminhar da juventude, já havia decidido o meu futuro: seria professora de alfabetização. (Trecho da narrativa da professora Sonia, lida no encontro de formação de 26/3/2013).

Todo professor é um livro e, consequentemente, uma promessa de leitura para seus alunos. A questão é saber se esse livro se renova e se revitaliza na própria prática do ensino; de que maneira esse livro se deixa fruir pelos alunos-leitores e se esse livro se abre à reflexão e ao posicionamento dos leitores, permitindo a produção de muitos outros livros. (SILVA, 1999, p. 30).

Para Benjamin (1984, p. 78), a criança, ao ler, “[...] mistura-se com os personagens de maneira muito mais íntima que o adulto. $\mathrm{O}$ desenrolar e as palavras trocadas atingem-na com força inefável, e quando ela se levanta está envolta pela nevasca que soprava da leitura".

Práxis Educativa, Ponta Grossa, v. 11, n. 2, p. 410-433, maio/ago. 2016 Disponível em: <http://www.revistas2.uepg.br/index.php/praxiseducativa> 
Uma "Rocinha" de livros: percursos poéticos dos processos de formação de uma professora...

Para tornar-se um leitor, é necessário penetrar no mundo dos textos, tê-los à disposição, formar expectativas e formular hipóteses em que o verbal e o não-verbal colaboram na construção de sentidos. A leitura é, portanto, um processo: o processo de formar o leitor crítico, aquele que tem o direito de indagar, questionar, negar, discordar. Bakhtin (2000, p. 350) acentua que, "[...] se nada esperamos da palavra, se sabemos de antemão tudo quanto ela pode dizer, esta se separa do diálogo e se coisifica". Diante disso, a sala de aula é o espaço de oralidade, de trocas, de conhecimento e de reconhecimento de identidades e autorias.

\begin{abstract}
Com o objetivo de intensificar ainda mais o diálogo com a realidade das crianças surgiu o projeto Fotografias. As abordagens se concentraram sobre a Rocinha viabilizando conbecer os múltiplos sentidos de inscrição dos moradores, entre os quais, as crianças da escola. A proposta convidava o grupo a uma apresentação visual dos locais na comunidade que fossem significativos para cada um. De posse da máquina fotográfica, as próprias crianças organizaram-se em pequenos grupos na comunidade e começaram a fotografar. A revelação do filme mostrou uma poesia de cores nas casas, ruas, lajes e no verde de uma paisagem retratada como parte integrante do cotidiano de quem vivia na Rocinha. $O$ passo seguinte foi o de complementar escolhas justificando-as através do texto escrito. O conjunto de fotografias, quando exposto no mural do corredor da escola, pode ressignificar entendimentos sobre uma comunidade que enfrentava, ao longo de anos, crescentes situações de violência e opressão; um espaço que era a referência de vida e infância da grande maioria das crianças e funcionários adultos da escola. Estabeleceu-se um elo, onde o cotidiano da comunidade passava a dialogar com o cotidiano escolar. $A$ escola abrindo suas portas para uma relação bem maior: uma relação de encontro e não mais de isolamento ou distanciamento. (Trecho da narrativa da professora Sonia, lida no encontro de formação de 16/4/2013).
\end{abstract}

O fragmento da realidade gravado na fotografia representa o congelamento do gesto e da paisagem, e, portanto, a perpetuação de um momento, em outras palavras, da memória: memória do indivíduo, da comunidade, dos costumes, do fato social, da paisagem urbana, da natureza. A cena registrada na imagem não se repetirá jamais. Kossoy (2001) aponta que o momento vivido, congelado pelo registro fotográfico, é irreversível. A construção coletiva das visualizações permitiu imprimir novos significados ao ato de contemplar. Perceber as entrelinhas das imagens, o não-dito das cenas, era poder estar constantemente exercitando o interpretar, o desvendar de uma cultura. Histórias presentificam-se por meio de uma coleção de fotos que, igual a um livro quando relido, sempre apresenta um fato novo, um detalhe que passara despercebido, uma narrativa que continua sendo grafada. Evidencia-se, assim, o caráter polissêmico da fotografia: uma mesma imagem permitindo diversas interpretações.

Destaco algumas das escritas sobre as fotografias tiradas: já não havia mais o receio de escrever e inscrever-se nas linhas do papel:

"A foto que eu tirei foi da Pedra da Gávea. Sabe por quê? Eu gosto dela porque eu vou na minha varanda e olho bastante e penso na minha vida. Ela é muito grande e meus colegas já foram lá e me falaram que é muito bom. Um dia, eu também vou lá” (Gabriela);

"Eu gosto desse lugar porque eu posso soltar pipa, andar de bicicleta e fazer muito mais coisas. Essa é a minha área de lazer para eu brincar com meus amigos. Tem um pé de jamelão, muitos pés de jaca e de mamão" (Daniel).

"Eu escolbi esse lugar porque ele é maravilhoso e lindo. Eu adoro muito e passo o dia olhando da minha janela e fico pensando na vida, o que quero para a minha vida quando crescer" (Samara). (Trechos da narrativa da professora Sonia, lida no encontro de formação de 16/4/2013).

Práxis Educativa, Ponta Grossa, v. 11, n. 2, p. 410-433, maio/ago. 2016 Disponível em: <http://www.revistas2.uepg.br/index.php/praxiseducativa $>$ 
Figura 6 - Pedra da Gávea - Fotografia de Gabriela (10 anos)

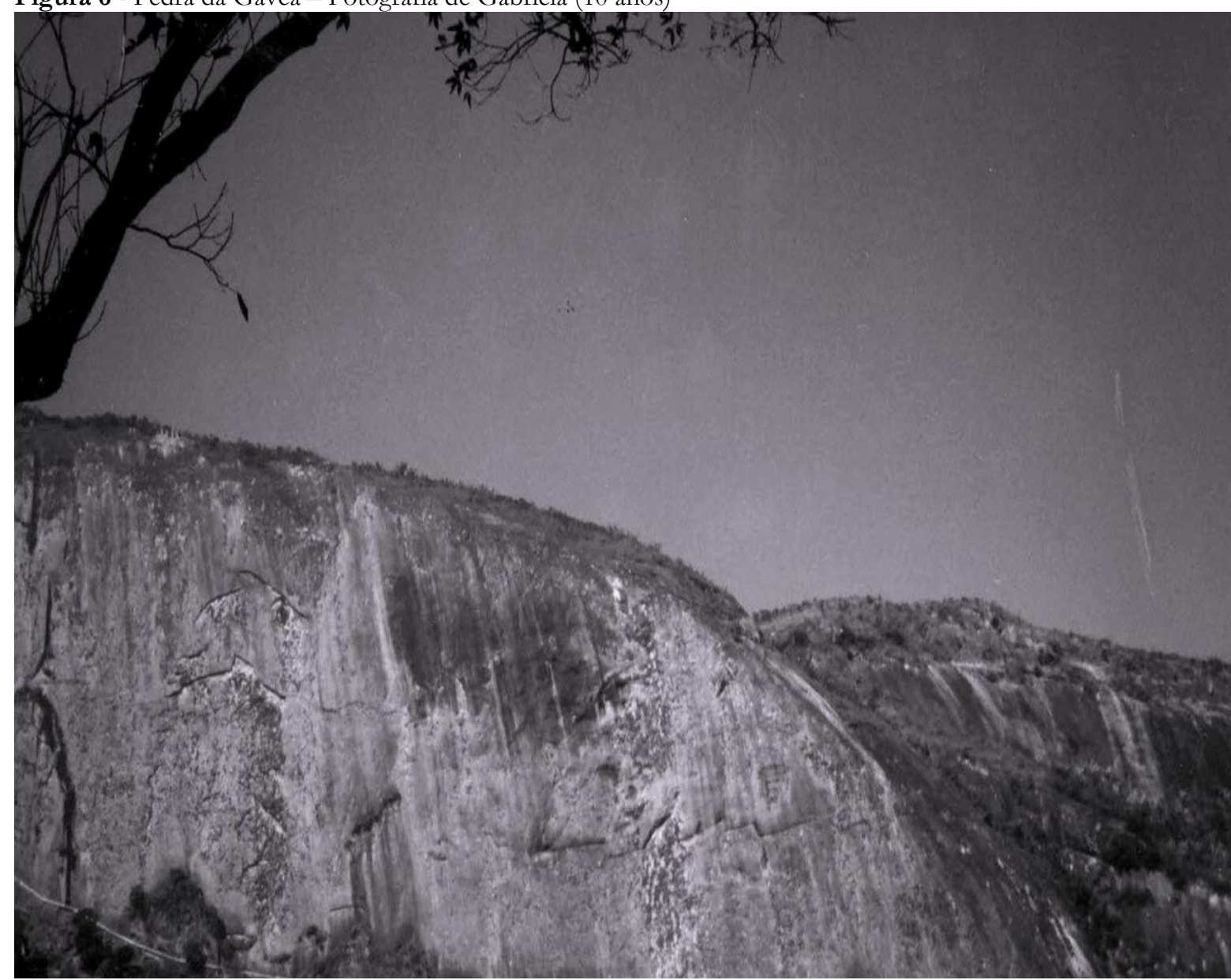

Fonte: Acervo da pesquisa.

Figura 7 - Pedra da Gávea ao fundo - Fotografia de Jean (11 anos)

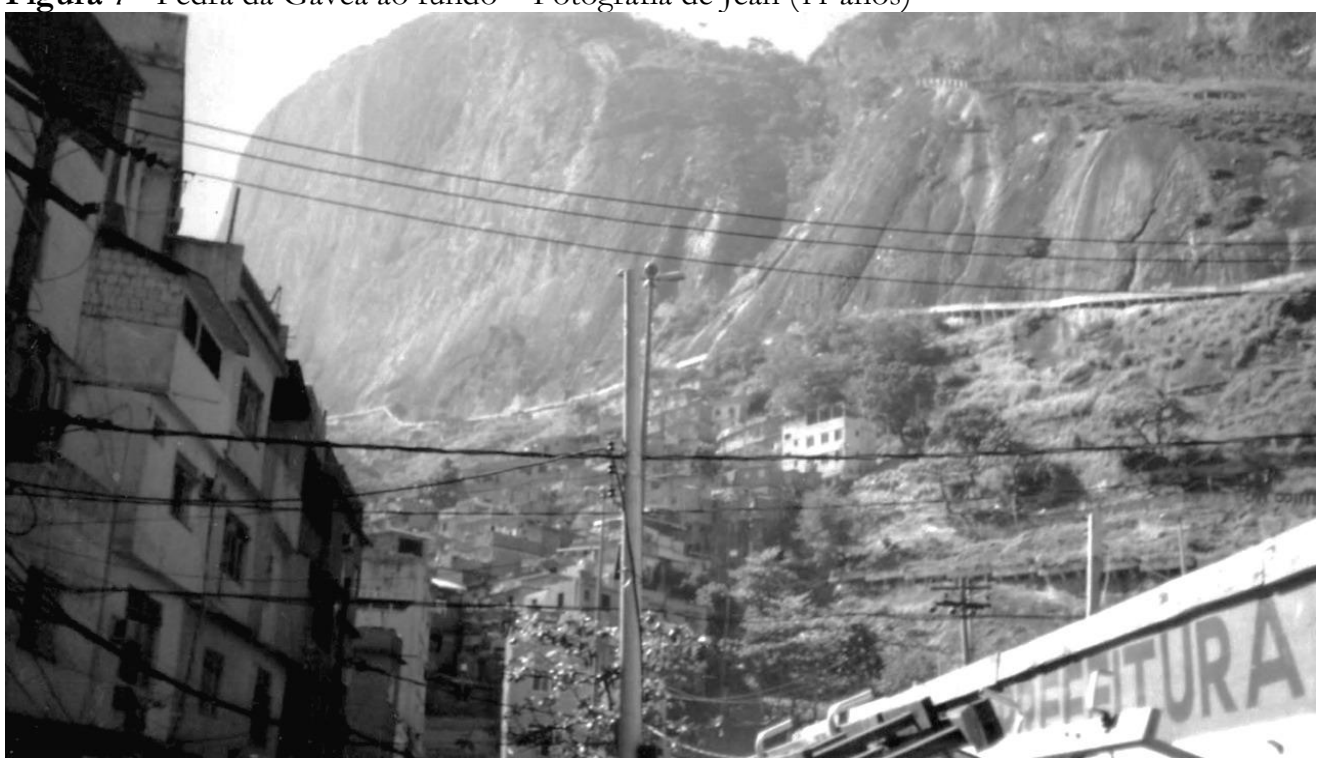

Fonte: Acervo da pesquisa.

Práxis Educativa, Ponta Grossa, v. 11, n. 2, p. 410-433, maio/ago. 2016 Disponível em: < http://www.revistas2.uepg.br/index.php/praxiseducativa> 
Uma "Rocinha" de livros: percursos poéticos dos processos de formação de uma professora...

As crianças e os pequenos jovens compreenderam que "[...] é experiência aquilo que 'nos passa', ou que nos toca, ou que nos acontece, e ao nos passar nos forma e nos transforma. Somente o sujeito da experiência está, portanto, aberto à sua própria transformação" (LARROSA, 2002, p. 25-26, grifo do autor); e puderam significar o mundo em que viviam contribuindo na medida em que se perceberam sujeitos ativos, protagonistas de uma ação, autores de história e construtores de conhecimento. Na dimensão poética das criações, na diversidade de linguagens apropriadas, na sensibilização de olhares e escutas, aprenderam e se conheceram ainda mais. Conquistaram autonomia, autoria e reconhecimento e engendraram uma nova ação que se materializou no projeto "Livros pela Rocinha: leia um livro e espalhe essa ideia".

\section{Uma Rocinha de livros}

No ano de 2010, por força das fortes chuvas que caíram sobre a cidade do Rio de Janeiro, a região do Laboriaux tornou-se imensamente perigosa, sendo considerada pela Defesa Civil como área de risco. A escola pública e uma parte da comunidade de seu entorno teve de se mudar, ainda que provisoriamente, em função dos deslizamentos de terra e do risco de desabamento na região. A escola pública foi deslocada para o Horto Florestal da cidade, no bairro Jardim Botânico, onde funcionou, por quase dois anos, no segundo andar de uma outra escola. Ao longo desse período, a escola recebeu uma grande doação de livros que ficaram encaixotados por não haver espaço na diminuta sala de leitura. De volta à Rocinha, a sala de leitura é reativada e as caixas de livros são abertas. Muitos livros não se adequavam ao público da escola, pois eram destinados a jovens e a adultos, e a equipe pedagógica decidiu disponibilizá-los para a comunidade. A professora Sonia narra como tudo começou:

\footnotetext{
A rąão maior de termos pensado nesse projeto, que já foi desenvolvido no ano de 2013, mas será repetido neste ano, é oportunizar a leitura entre todos os moradores do Laboriaux, independentemente de terem qualquer vínculo com a nossa escola. A ideia surgiu quando não estávamos na Rocinha. Explico-me. Em abril de 2010, nossa escola precisou ausentar-se temporariamente da Rocinha devido a uma forte chuva que causou desabamentos e mortes nos arredores. Ficamos até meados de $2012 \mathrm{em}$ um dos andares de uma escola pública no Horto. Nessa época assumi tanto a sala de leitura, quanto uma "turma de projeto" - crianças e jovens que ainda não dominavam a leitura e a escrita apesar de anos de escolaridade. Lá no Horto, recebemos de doação três grandes caixas de livros de literatura para jovens e adultos. Como estávamos distanciados da comunidade, os livros ficaram guardados. De volta à Rocinha, no final do ano de 2012, decidimos, en e a equipe pedagógica da escola, disponibilizar esse acervo para a comunidade. Com essa ideia na cabeça e em parceria com as crianças demos os primeiros passos para a realização do projeto que foi batizado, por sugestão das crianças de "Livros pela Rocinha: leia um livro e espalhe essa ideia". (Trecho do caderno de campo da professora Sonia).
}

A intenção do projeto é distribuir livros organizados em caixas de papelão pelos estabelecimentos do Laboriaux para que as crianças, suas famílias e a comunidade possam pegálos por empréstimo sem a necessidade de prazos para a devolução ou preenchimento de fichas. A narrativa de Sonia permite-nos vislumbrar a organização e o desenvolvimento do projeto.

Quando voltamos para a Rocinha, decidimos criar um projeto para contagiar a comunidade com o mesmo prazer que temos de ler, professoras e crianças. Conseguimos algumas doações de literatura infantil para complementarmos esse acervo e escolhemos uma das turmas de nossa escola para nos auxiliar na organização, distribuição e "controle" dos livros a serem emprestados.

A turma escolbida para ficar à frente das ações foi a "turma de projeto", composta por crianças e jovens que precisavam ser mais conquistados pela leitura. As crianças dessa turma pintaram seus coletes e as demais turmas da escola ajudaram na confecção das caixas de papelão. Relacionamos os livros de cada uma das 6 caixas somente para sabermos quais estariam em cada uma. Elaboramos bilhete que foram colados na contracapa de cada exemplar explicando a dinâmica dos empréstimos:

Práxis Educativa, Ponta Grossa, v. 11, n. 2, p. 410-433, maio/ago. 2016 Disponível em: <http://www.revistas2.uepg.br/index.php/praxiseducativa $>$ 


\begin{abstract}
"Queremos contagiá-lo com o mesmo prazer que temos ao ler. Alguns livros desta caixa podem não estar muito novos, mas as histórias que narram não envelhecem jamais! Com certeza você vai se encantar! Escolha o livro que desejar e o devolva quando puder. Não precisa assinar nenbum documento. Quando devolvê-lo, se quiser, pode deixar no envelope sua opinião por escrito sobre a leitura. Vamos adorar conhecê-la".

Eu, as crianças e Vilma ${ }^{9}$, funcionária da escola, passeamos pelo Laboriaux para escolhermos os locais onde as caixas seriam colocadas. Conversamos com os moradores e comerciantes para explicar a finalidade do projeto e recebemos total apoio. Todo esse processo levou cerca de três meses devido às imprevisibilidades do cotidiano. Quando finalmente conseguimos organizar tudo já estávamos em julho.

Saimos em um novo passeio para distribuirmos as caixas. Os locais escolbidos foram: a padaria, a farmácia, o açougue, o sacolão do Silvio, o sacolão do Nonato, o bar do seu Francisco, o restaurante $V$ isual e o Posto de Saúde próximo à rua Um. Em cada um desses lugares, uma pessoa do local ficou responsável em colocar a caixa todos os dias na porta e retirá-la ao final do dia. Além disso, as crianças e jovens da turma faziam visitas diárias a esses locais - quando estivessem vindo para a escola ou voltando para suas casas - para observar se havia algum bilhete, se os livros estavam sendo levados, se havia alguma outra doação. Assim, todo o caminho que vai da Rua Um até a nossa escola foi contemplado com livros de literatura. (Trecho do caderno de campo da professora Sonia).
\end{abstract}

Figura 8 - Caixas de livros prontas para distribuição - Fotografia de Luana (10 anos)

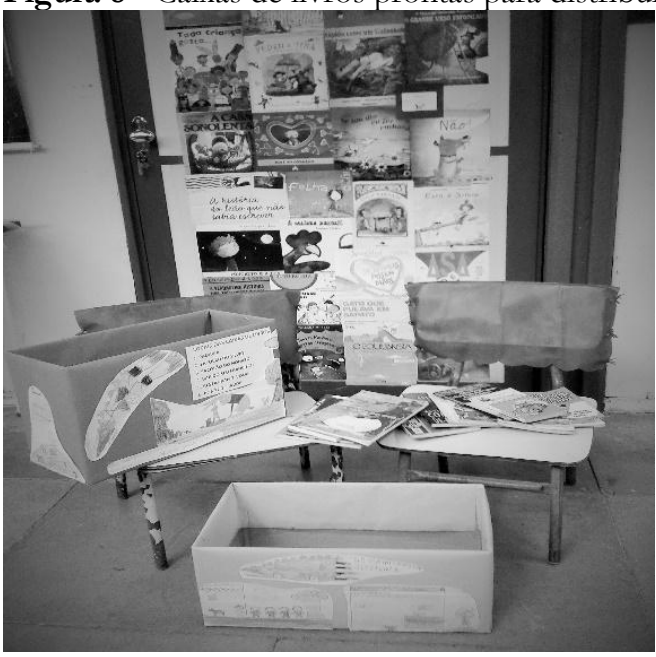

Fonte: Acervo da pesquisa.

Figura 9 - Preparando as caixas para distribuição - Fotografia de Raphael (10 anos)

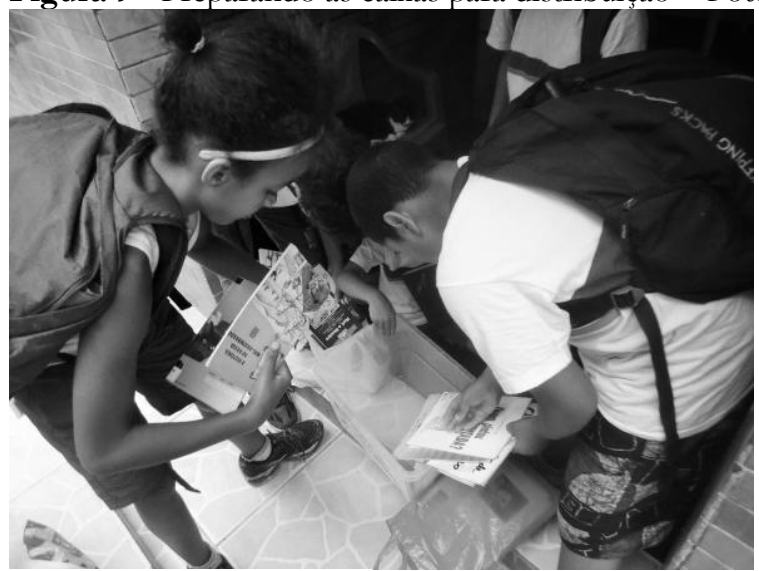

Fonte: Acervo da pesquisa.

Além do objetivo de conquistar a comunidade para partilhar o prazer da leitura, o desejo maior de Sonia e de seus alunos era possibilitar o acesso e a circulação de livros pelas crianças,

${ }^{9}$ Omitimos o nome da profissional por uma questão ética.

Práxis Educativa, Ponta Grossa, v. 11, n. 2, p. 410-433, maio/ago. 2016 Disponível em: <http://www.revistas2.uepg.br/index.php/praxiseducativa> 
pelos jovens e pelas famílias que, dessa forma, também poderiam compartilhar suas leituras entre si e com todos que desejassem. Fazer circular os textos literários entre a comunidade com a possibilidade de, ao término de uma leitura, trazer o livro e trocá-lo por outro, foi um dos principais efeitos do projeto, na medida em que, já nos primeiros dias, após a instauração do projeto, não havia quase livros disponíveis nas caixas.

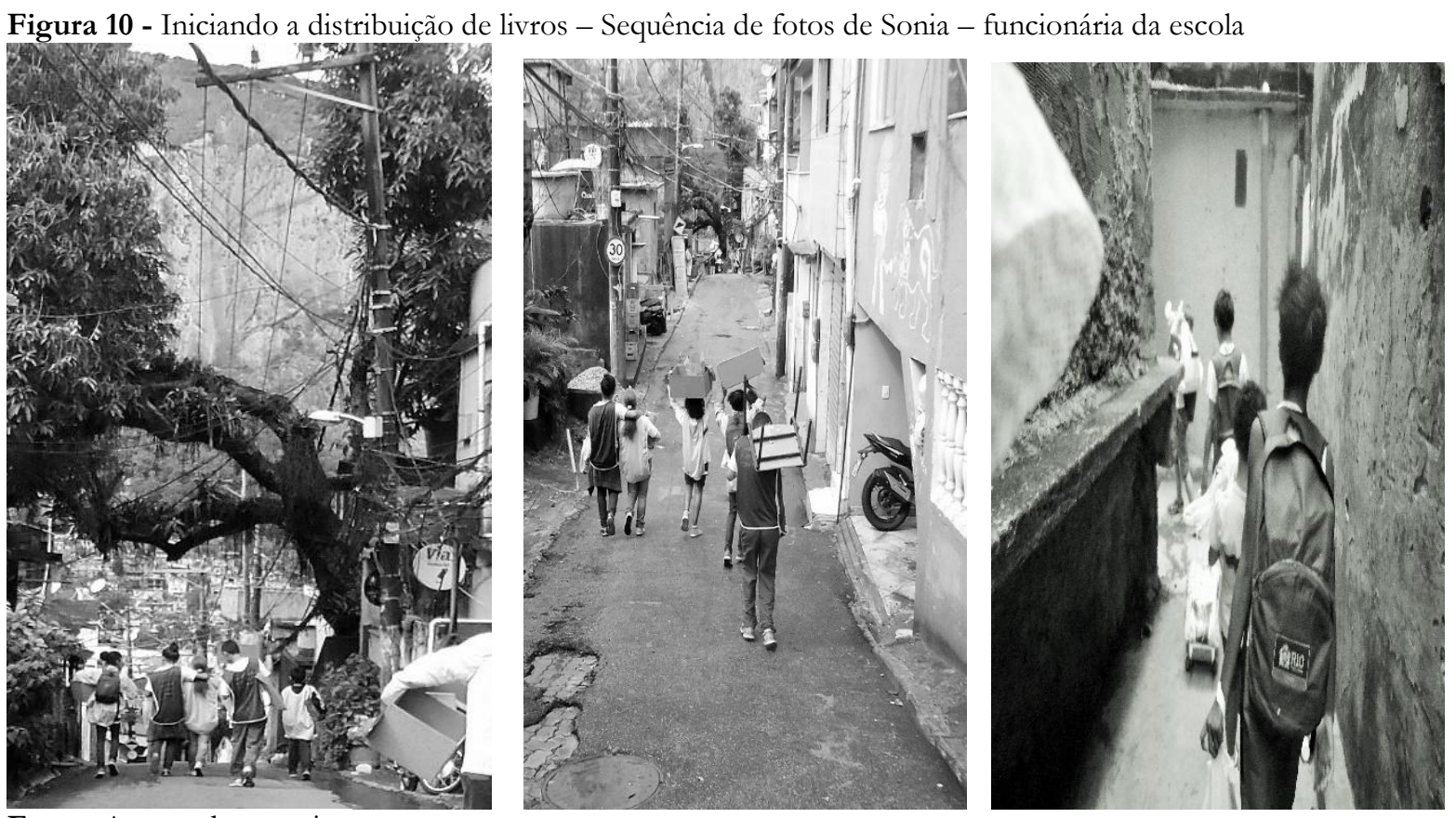

Fonte: Acervo da pesquisa.

Figura 11 - Conferindo as caixas de livros - Sequência de fotos de Sonia - funcionária da escola

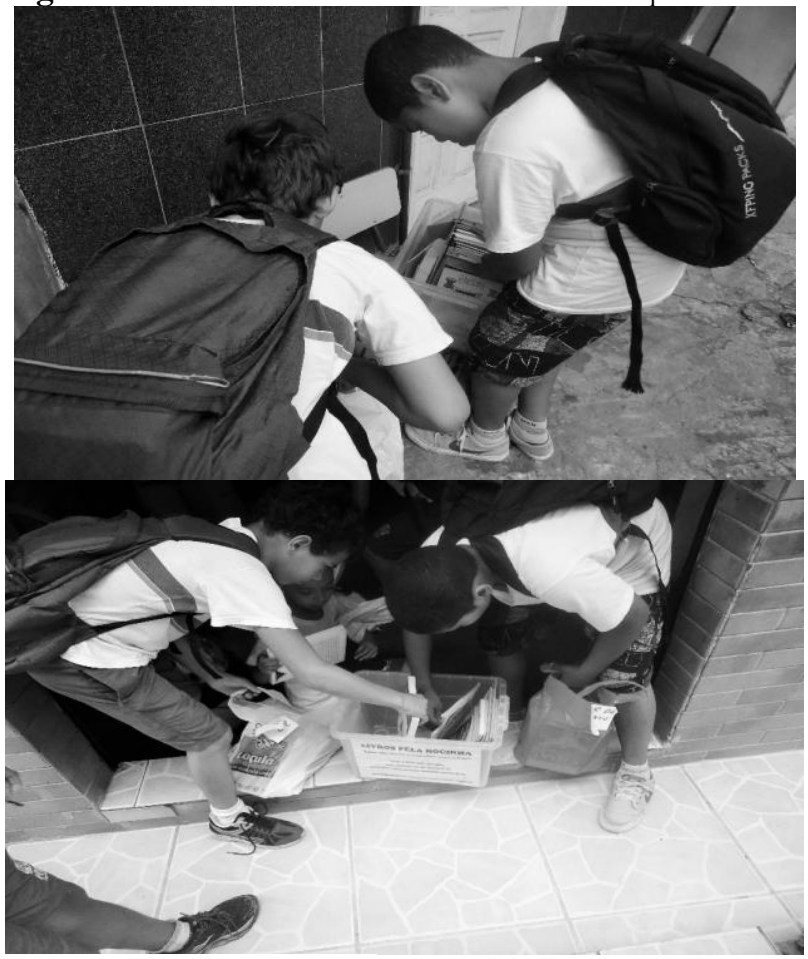

Fonte: Acervo da pesquisa.

Figura 12 - Caminhando em direção do Restaurante Visual - Fotografia de Juciara (12 anos)

Práxis Educativa, Ponta Grossa, v. 11, n. 2, p. 410-433, maio/ago. 2016 Disponível em: <http://www.revistas2.uepg.br/index.php/praxiseducativa> 


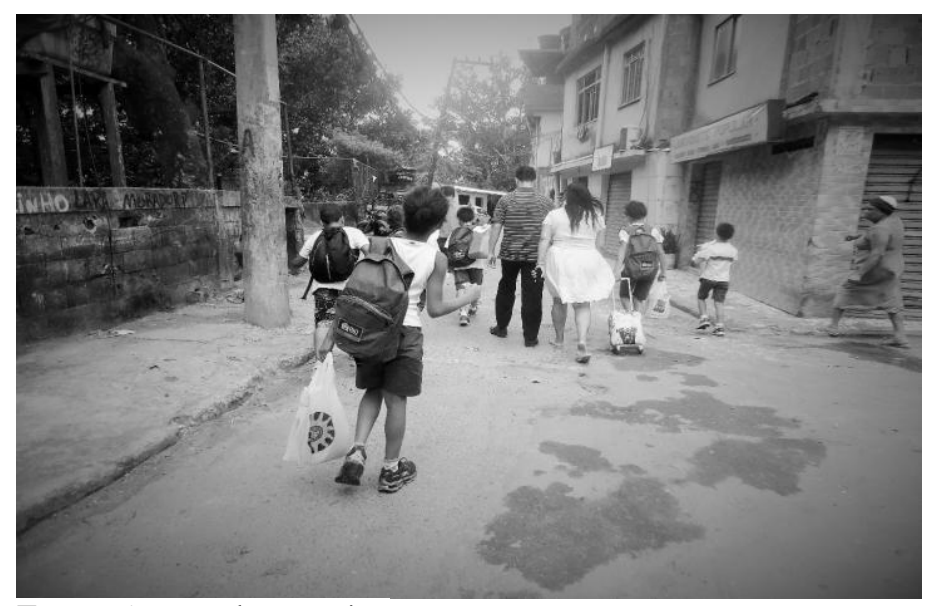

Fonte: Acervo da Pesquisa.

Figura 13 - Restaurante Visual - Fotografia de Juciara (12 anos)

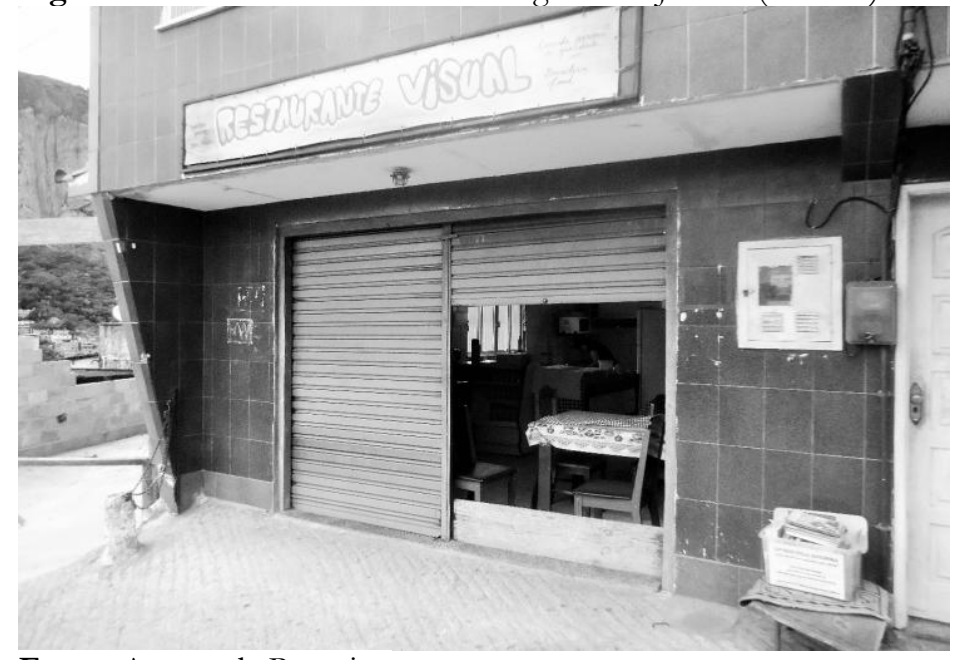

Fonte: Acervo da Pesquisa.

Figura 14 - Caixa de livros do restaurante Visual - Fotografia de Juciara (12 anos)

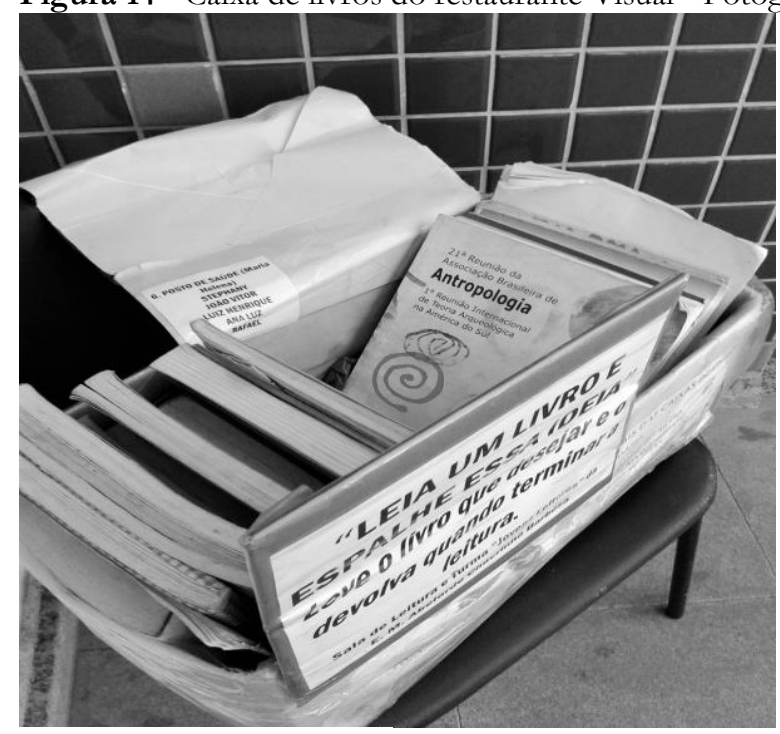

Fonte: Acervo da Pesquisa.

Práxis Educativa, Ponta Grossa, v. 11, n. 2, p. 410-433, maio/ago. 2016 Disponível em: < http://www.revistas2.uepg.br/index.php/praxiseducativa> 
Uma "Rocinha" de livros: percursos poéticos dos processos de formação de uma professora...

Por outro lado, o rodízio acabou comprometido porque muitos dos exemplares não foram devolvidos. Isso acabou incentivando a doação de livros por parte da comunidade, pois, como dizem as crianças, "as caixas não podem ficar vazias". Apesar de as publicações doadas não terem sido de textos literários, mas sim de livros didáticos e técnicos, essas doações foram respeitadas e deixadas nas caixas de livros para aqueles que desejassem levar. Sonia chama atenção para o fato de que:

\begin{abstract}
O projeto "Livros pela Rocinha: leia um livro e espalhe essa ideia" envolven toda a escola e a comunidade do Laboriaux, que participou desde a doação de livros até o acompanbamento das caixas espalhadas pelos diversos lugares. As crianças, no periodo da Bienal, redigiram circulares, que foram emitidas para todas as editoras pedindo doações de livros. Como nossa escola está situada em um local de difícil acesso, recebemos algumas doaçoes na casa da diretora adjunta, na Tijuca e pudemos, dessa forma, reabastecer as caixas e dar continuidade ao projeto. Confirmamos que a comunidade gosta de ler e desconstruimos as visões estereotipadas de que a população menos privilegiada economicamente não gosta de ler. Todos os dias, quando chego à escola, trago jornais gratuitos e os deixo na "birosca" da esquina. Os moradores próximos já me cobram: "Cadê as notícias?". Assim como gostam de ler jornais também gostam de ler livros. Acontece que livros são caros, então, se pudermos oferecê-los gratuitamente, é muito melhor. (Trecho do caderno de campo da professora Sonia).
\end{abstract}

\title{
Conclusão
}

A escola pode ser espaço de leitura e de escrita com real sentido de comunicação; assim, um ato solitário converte-se em diálogo com o outro. Histórias e identidades inscritas no cotidiano da sala de aula possibilitaram ir além das análises da construção e da reconstrução de saberes pedagógicos favorecendo uma interlocução mais ampla com a diversidade social humana da escola que partilha acontecimentos, rotinas, emoções - vida! - em um terreno fértil de relações.

As narrações representam não somente uma trajetória individual, mas o descortinar de tramas coletivas fundadas na relação de alteridade em que os discursos se acentuam pela presença da multiplicidade de vozes que emergem da realidade educativa e fazem da formação (inicial e continuada) de professoras alfabetizadoras um ato responsável.

Ninguém pode contar uma história que é nossa. O objetivo maior do trabalho de professoras e de crianças com leituras e escritas é o de ressaltar que todos podem ser autores de suas próprias histórias. O desafio, portanto, é auxiliar na formação de leitores críticos e autônomos. Por meio da leitura, temos infinitas possibilidades de criarmos e nos recriarmos assumindo a autoria daqueles que desejam não só se transformar, mas transformar o seu entorno. Nesse percurso, apropriamo-nos do que já está dito e escrito como também nos reconhecemos capazes de dizer e escrever as nossas palavras.

A escola pública do Laboriaux, na medida em que se abre também às famílias e à comunidade, acaba por se constituir como referência de leitura para todo aquele que se sentir tocado por esse desejo. Basta, para isso, que possamos investir ainda mais em uma litera(lei)tura que transcenda os muros da escola e nos torne ainda mais humanos ao transformarmos memórias individuais em coletivas, assumindo uma postura de acolhimento do outro e de seu saber.

Nessa agitação que antecede o fim de ano letivo, decidi faz̧er uma avaliação do projeto "Livros pela Rocinha” e me deixei surpreender pelos comentários dos jovens de nossa escola. Caio acha interessante ver livros, ler livros e conversar sobre livros. Alice acredita que o contato maior com livros mudou seu comportamento: ela comenta que nem está fazendo muita bagunça! Para Alice, o projeto a incentivou a ler e a fez descobrir novas aventuras. Quando essa mesma menina está brava ela lê porque a leitura a deixa aliviada. Paulo Vitor diz que a leitura mudon sua vida e Maria Eduarda passon a se

Práxis Educativa, Ponta Grossa, v. 11, n. 2, p. 410-433, maio/ago. 2016 Disponível em: <http://www.revistas2.uepg.br/index.php/praxiseducativa $>$ 
interessar mais por livros e a discutir o que lê com os amigos. Miguel já gostava de ler, mas agora ama!!! Maria Carolina adora as ilustracões. Kailane acha a leitura mágica pois a faz sentir-se nas nuvens. Luís Fabiano acredita que o livro muda a gente e ainda afirma que aquele que se esforça vai conseguir ler. Allan é bem prático: saber ler o deixa orgulhoso porque simplesmente ele não quer ser burro! Patrícia acredita que ler é um jeito de aprender. João Vitor se distrai com a leitura. Para Miguel Caique, "quando a gente lê, se imagina dentro do livro e isso é muito prazeroso". A leitura, para Anna, é reconfortante: quando ela lê, deixa de ficar estressada e ajuda também a diminuir as saudades que sente de sua familia. Gilmário comenta que ler é uma coisa boa! Simples assim! Além dos livros, adoramos essas nossas crianças e jovens que estão constantemente surpreendendo e nos deixando sem fala. (Trecho do caderno de campo da professora Sonia).

São essas as razões pelas quais queremos permanentemente divulgar práticas leitoras, descobrir os tantos outros que habitam em nós e nas crianças de nossas turmas, nos abrir a novos desafios. Qual o lugar da palavra na formação, na educação? Sem dúvida, a palavra como possibilidade de emancipação. Que a palavra não seja o jugo, mas a liberdade! Importa saber as marcas que ficaram, as experiências que afetaram. E, nesse sentido, compreender a dimensão da palavra lida, falada, ouvida e, até mesmo, silenciada. Concluímos que precisamos permanentemente (re)construir espaços plurais de leitura - e de fala, de escrita, de escuta!!!

\section{Referências}

ALVES, L. P. Aprender como invenção: outra política cognitiva numa escola (re)inventada. 2013. 324 f. Tese (Doutorado em Educação) - Universidade Federal Fluminense, Niterói, 2013.

ALVES, M. P. C. A Leitura na sala de aula de Língua Portuguesa e a formação de leitores responsivos. In: FREITAS, M. T. A. (Org.). A responsividade bakhtiniana: na educação, na estética e na política. Juiz de Fora: UFJF, 2011. p. 276-278.

BAKHTIN, M. Questões de literatura e estética. São Paulo: Hucitec, 1998.

BAKHTIN, M. Estética da criação verbal. São Paulo: Martins Fontes, 2000.

BARros, M de. Gramática Expositiva do Chão. In: BARROS, M. de. Poesia completa. São Paulo: Leya, 2010. p. 119.

BENJAMIN, W. Reflexões: a criança, o brinquedo, a educação. São Paulo: Summus, 1984.

FREIRE, P. Pedagogia da autonomia. Rio de Janeiro, RJ: Paz e Terra, 1996.

FREIRE, P.; FAUNDEZ, A. Por uma pedagogia da pergunta. São Paulo: Paz e Terra, 1991.

FURNARI, E. Lolo Barnabé. São Paulo: Moderna, 2000.

GARCIA, R. L.; ZACCUR, E. (Orgs.). Alfabetização: reflexões sobre saberes discentes e saberes docentes. São Paulo: Cortez, 2008.

GERALDI, J. W. A diferença identifica. A desigualdade deforma. Percursos bakhtinianos de construção ética e estética. In: FREITAS, M. T. (Org.). Ciências humanas e pesquisa. São Paulo: Cortez, 2003. p. 39-56.

GERALDI, J. W. A aula como acontecimento. São Carlos: Pedro \& João, 2010.

Práxis Educativa, Ponta Grossa, v. 11, n. 2, p. 410-433, maio/ago. 2016 Disponível em: <http://www.revistas2.uepg.br/index.php/praxiseducativa $>$ 
Uma "Rocinha" de livros: percursos poéticos dos processos de formação de uma professora...

GERALDI, J. W. Alfabetização e letramento: perguntas de um alfabetizado que lê. In: ZACCUR, E. (Org.). Alfabetização e letramento: o que muda quando muda o nome? Rio de Janeiro: Rovelle, 2011. p. 13-32.

GIOVANI, F., GARCIA, C. B. O sujeito ético e estético. In: Rodas de conversas bakhtinianas. Bakhtin e a atividade estética: novos caminhos para a ética. São Carlos: Pedro \& João, 2010. p. 99-100.

KOSSOY, B. Fotografia \& História. São Paulo: Ateliê, 2001.

LARROSA, J. Notas sobre a experiência e o saber da experiência. Revista Brasileira de Educação, Rio de Janeiro, n. 19, p. 20-28, jan./abr. 2002.

LARROSA, J. Dar a ler... quizá - Notas para uma dialógica de la transmisión. In: YUNES, E.; OSWALD, M. L. (Orgs.). A Experiência da leitura. São Paulo: Loyola, 2003. p. 117-131.

NAGAI, E. Teses Bakhtinianas. In: Rodas de conversas bakhtinianas. Bakhtin e a atividade estética. Novos caminhos para a ética. São Carlos: Pedro \& João, 2010. p. 86-89.

PÉREZ, C. L. V.; ALVES, L. P. Injustiças cognitivas: ressignificando os conceitos de cognição, aprendizagem e saberes no cotidiano da escola. Relatório de Pesquisa. Rio de Janeiro. FAPERJ, 2009.

PÉREZ, C. L. V; SILVESTRI, M. L. A criação de uma revista eletrônica na escola: uma experiência coletiva de formação. In: ENCONTRO NACIONAL DE DIDÁTICA E PRÁTICA DE ENSINO - ENDIPE, 17., 2014, Fortaleza. Anais... Fortaleza: UECE, 2014.

PONZIO, A. Procurando uma palavra outra. São Carlos: Pedro \& João, 2010.

ROCHA, R. A menina que aprendeu a voar. Rio de Janeiro: Salamandra, 1998.

SACRISTÁN, G. Currículo e diversidade cultural. In: SILVA T. T.; MOREIRA, A. F. (Orgs.). Territórios contestados: o currículo e os novos mapas políticos e culturais. Rio de Janeiro: Vozes, 1995. p. 82-113.

SILVA, E. T. De olhos abertos: reflexões sobre o desenvolvimento da leitura no Brasil. São Paulo: Ática, 1999.

TODOROV, T. A literatura em perigo. Rio de Janeiro: DIFEL, 2010.

Recebido em 30/10/2014

Versão corrigida recebida em 28/12/2015

Aceito em 06/01/2016

Práxis Educativa, Ponta Grossa, v. 11, n. 2, p. 410-433, maio/ago. 2016 Disponível em: <http://www.revistas2.uepg.br/index.php/praxiseducativa> 